Jørgensen, B.B., D’Hondt, S.L., and Miller, D.J. (Eds.)

Proceedings of the Ocean Drilling Program, Scientific Results Volume 201

\title{
1. LEG 201 SYNTHESIS: CONTROLS ON Microbial Communities in DeEply BURIED SEDIMENTS'
}

\author{
Bo Barker Jørgensen, ${ }^{2}$ Steven L. D'Hondt, ${ }^{3}$ and D. Jay Miller ${ }^{4}$
}

\begin{abstract}
Leg 201 of the Ocean Drilling Program was the first ocean drilling expedition dedicated to the study of life deep beneath the seafloor, a challenge that has since become an integral part of the Integrated Ocean Drilling Program. Seven sites were drilled in the Peru margin and the eastern equatorial Pacific, ranging in water depth from 150 to $5300 \mathrm{~m}$ and in sediment depth from 0 to 420 meters below seafloor (mbsf), corresponding to sediment ages of Holocene to late Eocene. Continuous contamination tests with perfluorocarbon and fluorescent microbead tracers were conducted during drilling, and improved shipboard procedures were developed for anaerobic and aseptic handling of sediment samples. Sufficiently uncontaminated sediment was thus obtained from all sites for detailed microbiological and biogeochemical analyses. Microbial cells were detected and enumerated in cores from the sediment surface down to oceanic basalt; the oldest sediment was $\sim 35 \mathrm{Ma}$. The prokaryotic population size varies in relation to geochemical zonations and to sediment properties determined by oceanographic conditions at the time of deposition. Cell densities increase from the Pacific openocean sites to the upwelling region of the Peruvian shelf, where densities at a sulfate-methane transition zone reach $10^{10}$ cells $/ \mathrm{mL}$, the highest yet recorded in subsurface sediments. Molecular screening of the subsurface microbial communities reveals a large diversity of bacterial and archaeal phylogenetic lineages, most with no or very few cultured representatives. Only a few sequences related to classical sulfate-reducing bacteria and methanogenic archaea are represented in the clone libraries, even where sulfate reduction and methanogenesis are the
\end{abstract}

${ }^{1}$ Jørgensen, B.B., D'Hondt, S.L., and Miller, D.J., 2006. Leg 201 synthesis: Controls on microbial communities in deeply buried sediments. In Jørgensen, B.B., D'Hondt, S.L., and Miller, D.J. (Eds.), Proc. ODP, Sci. Results, 201, 1-45 [Online]. Available from World Wide Web: <http://www-odp.tamu.edu/ publications/201_SR/VOLUME/ SYNTH/SYNTH.PDF>. [Cited YYYYMM-DD]

2Department of Biogeochemistry, Max-Planck-Institute for Marine Microbiology, Celsiusstrasse 1, 28359 Bremen, Germany. bjoergen@mpibremen.de

${ }^{3}$ Graduate School of Oceanography, University of Rhode Island, South Ferry Road, Narragansett RI 028821197, USA.

${ }^{4}$ Integrated Ocean Drilling Program, Texas A\&M University, 1000 Discovery Drive, College Station TX 77845-9547, USA.

Initial receipt: 20 September 2005

Acceptance: 19 May 2006

Web publication: 25 July 2006

Ms 201SR-101 
B.B. JøRGENSEN ET AL.

predominant biogeochemical processes in the sediment. Quantification by deoxyribonucleic acid (DNA)/ribonucleic acid (RNA)-based techniques show that bacteria predominate over archaea and that a significant fraction of all cells contain ribosomes and thus can be confirmed as living and active microorganisms. Cultivation yielded a wide variety of bacterial isolates, including Proteobacteria, Actinobacteria, and Firmicutes, but no archaeal isolates. In situ temperatures range from $2^{\circ} \mathrm{C}$ at the sediment surface to $26^{\circ} \mathrm{C}$ at depth, and, accordingly, most isolates were mesophiles or moderate psychrophiles, but some thermophiles were also cultured. Diffusion-reaction modeling of pore water gradients was combined with direct radiotracer experiments to quantify major microbial processes such as sulfate reduction and methanogenesis. The results demonstrate the dependence of these processes on geochemical zonations and availability of energy sources. The generally low concentrations of key bacterial metabolites (acetate, formate, and $\mathrm{H}_{2}$ ) indicate continuing bacterial activity in the deep subsurface. Authigenic minerals such as pyrite, dolomite, or biogenic magnetite form as a result of the biogeochemical processes.

\section{INTRODUCTION}

Until a few decades ago, the microbial world was thought to be limited to the upper meters of the seabed, whereas deeper sediments were thought to be sterile in spite of significant amounts of organic material buried at much greater depths. Exploration of the deep subseafloor ecosystem started when the first evidence of microbial activity was provided by studies of methane formation and sulfate reduction in cores obtained from the Deep Sea Drilling Project (DSDP) (Claypool and Kaplan, 1974; Oremland et al., 1982; Whelan et al., 1986; Tarafa et al., 1987). In the late 1980s, John Parkes and Barry Cragg began systematically counting microbial cells in Ocean Drilling Program (ODP) cores (Cragg et al., 1990), an endeavor that over the following two decades led to a large amount of data on the population size of deep biosphere microorganisms (Parkes et al., 2000). For many years, these bacterial counts were considered with some skepticism among microbiologists, mainly because they contradicted the general understanding of minimum requirements for life and because of the difficulty of convincingly proving that the cells were not a result of contamination of the samples from the surface world. Beginning with ODP Leg 185, however, occasional contamination-tracing experiments showed that the vast majority of cells found in deeply buried sediments were indigenous to the sampled sediments (Smith et al., 2000a, 2000b). As the reality of a deep subseafloor ecosystem gradually became widely accepted, Whitman et al. (1998) made a bold global extrapolation based on available data. The authors came to the astonishing conclusion that prokaryotes in subseafloor sediments constitute a "hidden majority" equivalent to $1 / 2$ to $5 / 6$ of Earth's prokaryotic biomass and 1/10 to 1/3 of Earth's total living biomass. This vast population must play a critical role in global carbon cycling by controlling the amount of deposited organic material that becomes buried to great depth in the seabed and stored there for many millions of years. This ecosystem also controls biogenic methanogenesis, which is the main source of modern gas hydrates accumulating in the seabed, a reduced carbon reservoir that vastly exceeds the amount of carbon in all living organisms on Earth (Kvenvolden, 1993). 
B.B. JøRGENSEN ET AL.

Leg 201 was the first ocean drilling expedition dedicated to study of life deep beneath the seafloor (D'Hondt, Jørgensen, Miller, et al., 2003). Seven sites were drilled in open-ocean and ocean-margin provinces in the eastern tropical Pacific Ocean (Fig. F1; Table T1). Neogene deep-sea clays and Paleogene nannofossil ooze were cored at Peru Basin Site 1231. Miocene-Holocene carbonate and siliceous oozes and chalk were cored at Sites 1225 and 1226. Miocene-Holocene biogenic oozes and terrigenous sediments of the shallow Peru shelf were cored at Sites 1227, 1228, and 1229. Organic-rich Miocene-Holocene sediments were cored at Site 1230 on the Peru slope, in the accretionary wedge just landward of the Peru Trench. Among the sites drilled, the Peru margin location was particularly pertinent, as Leg 112 working in the same area was one of the earliest ODP expeditions to include study of subseafloor life (Cragg et al., 1990).

Leg 201 counted among its scientific staff a large contingent of microbiologists, biogeochemists, and chemists. An unprecedented range of samples was taken for microbiological and biogeochemical analyses, and many approaches were combined with the aim of identifying and quantifying subsurface populations of microorganisms and their metabolic activities. Onboard analyses of pore water chemistry provided detailed information about the chemical environment and zonation at each site and guided further microbiological sampling. Such data were later used for transport-reaction modeling of those biogeochemical redox processes that involved major pore water species. A novel approach for the JOIDES Resolution and ODP was the extensive use of radioactive isotopes for experimental determination of process rates using tracer methods that were driven to their highest sensitivity in order to detect extremely low rates of metabolism. A radioisotope van was installed on the drillship, and strict procedures were followed to exclude potential contamination. Cultivation of microorganisms was initiated on board the ship using a broad range of incubation techniques that should enable growth of very diverse physiological types of organisms. Because of the exceedingly slow growth of prokaryotes in the deep subsurface, incubations were continued in shore-based laboratories for up to several years until a number of successful isolates were obtained. Growth-independent methods based on deoxyribonucleic acid (DNA) or oxyribonucleic acid (RNA) were used extensively to analyze the size and diversity of in situ microbial populations and their functional key genes. In addition, analyses of physical properties, sedimentology, and geochemistry provided information on the environment of deep subsurface microorganisms and conditions controlling their activity. Important background information on stratigraphy, paleoceanography, and so on, was already available before the cruise because each site had been drilled before during earlier DSDP or ODP legs.

This chapter synthesizes results from Leg 201 with the main emphasis on data obtained through postcruise microbiological and biogeochemical research. Some of the data discussed are included in the following chapters of this volume, whereas other material is published elsewhere in international journals.
F1. Site location map, p. 38.

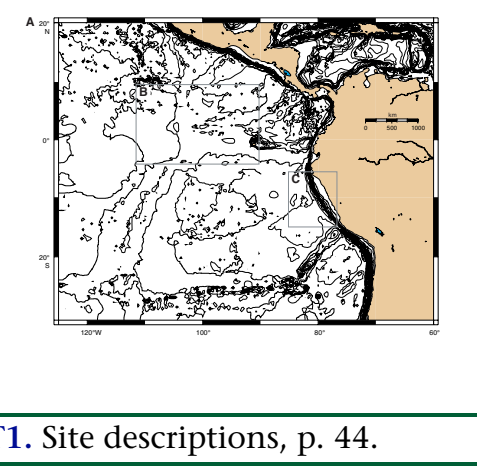




\section{BIOGEOCHEMISTRY}

\section{Burial and Degradation of Organic Matter}

Organic matter that is deposited and buried deeply in the seabed is the main carbon source for subseafloor microbial life. It is also the primary energy source available for the deep biosphere at the sites studied during Leg 201. No other energy sources were identified that could have an importance of comparable magnitude to that of buried organic carbon. Rates of mineralization and microbial activity, as quantified by modeling of major pore water constituents, relate closely to the organic contents of the sediments (D'Hondt, Jørgensen, Miller, et al., 2003; D'Hondt et al., 2004). Total organic carbon (TOC) was measured throughout the sediment column at all sites, with high-resolution sampling near the surface at selected sites (Meister et al., this volume b). TOC contents vary as much as a hundred-fold between the equatorial Pacific sites and the Peru margin sites. At open Pacific Site 1225, TOC contents are very low, $0.0-0.2 \mathrm{wt} \%$, whereas at Site 1226 they reach $1-2$ $\mathrm{wt} \%$, within the upper 150 meters below seafloor (mbsf). In the Peru Trench (Site 1230) TOC contents are higher (mostly 2-3 wt\%) but not as high as might be expected from the depletion of pore water sulfate already at 9 mbsf. The steep sulfate depletion at Site 1230 appears to be driven by methane ascending from deeper deposits rather than by high organic mineralization rates in the upper meters of the sediment.

On the Peruvian shelf, high phytoplankton productivity caused by upwelling supplies the underlying sediments with abundant organic matter. TOC values here scatter in the range of $1-12 \mathrm{wt} \%$. Particularly in Pleistocene-Holocene deposits at the shallower sites, TOC data indicate systematic variations that have been interpreted as glacial-interglacial cycles and may be associated with eustatic sea level variations (Wefer et al., 1990). These variations in carbon concentrations along with variations in carbon isotopic compositions and lignin contents probably reflect variations in marine productivity and diagenetic overprinting rather than variations in terrigenous inputs (Louchouarn et al., this volume). Sediment dating by accelerator mass spectrometry (AMS) ${ }^{14} \mathrm{C}$ measurements of bulk organic matter reveal that the Holocene section is largely absent at Peru shelf Site 1227, but sediment from the Pleistocene deglaciation is almost $6 \mathrm{~m}$ thick (Skilbeck and Fink, this volume). At Sites 1228 and 1229 the Holocene section is 2$2.5 \mathrm{~m}$ thick, whereas the upper Pleistocene section is thin and possibly eroded. A gradual increase with depth and time in the atomic $\mathrm{C} / \mathrm{N}$ ratio of organic matter from 12 to $>16$ within the same late Pleistocene-Holocene time window at Site 1227 demonstrates the result of microbial degradation on residual organic material (Prokopenko et al., this volume).

Through degradation of buried organic matter a part of the degradation products accumulate in pore water and can be detected as a pool of dissolved organic carbon (DOC). This pool consists of a complex mixture of organic molecules with large diversity in molecular weight and chemical composition (Burdige, 2002). During further microbial mineralization, the remaining DOC becomes increasingly refractory to enzymatic attack. Smith (this volume) analyzed bulk concentrations of DOC in pore water samples from Leg 201 cores using a high-temperature catalytic oxidation method (Sharp et al., 2002). DOC concentrations mostly showed limited variations of $0.2-0.5 \mathrm{mM}$ at the open 
Pacific sites and $0.5-12 \mathrm{mM}$ at the Peru margin sites. Surprisingly, DOC concentrations were very high in the subsurface sediment column of the Peru Trench (Site 1230), reaching a flat maximum of $20 \mathrm{mM}$ at 50$150 \mathrm{mbsf}$ (Smith, this volume). This DOC concentration is so high that a yellow coloration was clearly visible in freshly collected pore water (Shipboard Scientific Party, 2003d [Site 1230]) and a strong ultraviolet light absorption at $325 \mathrm{~nm}$ could be measured.

Fehn et al. (submitted [N1]) reviewed the iodine isotopic system as a tracer of organic material buried subsurface and included new data of Snyder et al. (submitted [N2]) from Site 1230. Iodine is strongly associated with organic material; therefore enrichment of the cosmogenic radioisotope ${ }^{129} \mathrm{I}$ with a half-life of 15.7 m.y. can be used to indicate the age of buried organic material. Pore fluids from Site 1230 are strongly enriched in iodine (Martin et al., 1993) and show a distinct decrease in the ratio of ${ }^{129}$ I to total I $\left({ }^{127} \mathrm{I}\right)$ with depth, from $920 \times 10^{-15}$ in surface sediments to $300 \times 10^{-15}$ below 100 mbsf. Fehn and coworkers calculated ages of 40-60 Ma for the pore fluids, which appear surprisingly old considering that they are derived from subducting sediments in an active margin. Whereas at Site 1230 sediments of Miocene age are subducting below Holocene-Pleistocene deposits, the source sediments for iodine, and possibly for some of the methane, thus appear to be of Eocene age or even older and may be stored as a large and very old reservoir within the overriding arc (Fehn et al., submitted [N1]).

Very little is known about the compound classes that compose DOC in deep subsurface sediments. In near-surface coastal and ocean-margin sediments total dissolved carbohydrates (DCHOs) represent 10\%-40\% of the total DOC (see Burdige, 2002, for a review). Burdige (this volume) analyzed DCHOs in Leg 201 pore water samples from all sites and found concentrations ranging from 0 to $\sim 1500 \mu \mathrm{M}$ C. Interestingly, there were no consistent downhole trends but there were distinct differences in concentration levels between sites. These differences do not relate to sediment organic content, however. Pacific Sites 1225 and 1231, as well as Peru Trench Site 1230, have the highest DCHO concentrations overall, whereas the Peru shelf sites with high organic content have low DCHO concentrations. Although there is presently not a clear interpretation of these concentration differences, it is apparent that several factors controlling production and degradation of DCHOs interact to determine DCHO concentrations.

Amino acid concentrations in the pore water similarly did not show systematic trends with increasing depth at any of the sites. The concentrations showed differences in the concentration ranges between sites with the highest concentrations found on the Peru margin and in the Peru trench Site 1230 (Mitterer, this volume). Aspartic acid, glutamic acid, serine, and glycine were detected and occurred in concentrations mostly in the range of 1-10 $\mu \mathrm{M}$. With geological age, the remaining amino acids in sediment organic material may undergo a slow racemization from the predominant L-forms to D-forms (Mitterer, 1993). An alternative source of D-forms is the degradation of bacterial cell walls in which the structural biopolymer, peptidoglycan, contains D-aspartate, D-glutamic acid, D-serine, and D-alanine (e.g., Schleifer and Kandler, 1972; Lomstein et al., in press). The D/L ratios of amino acids, however, did not show systematic increases with depth, and, thus, neither racemization nor an increasing contribution from bacterial cell walls could be demonstrated (Mitterer, this volume).

Methane concentrations in sulfate-depleted sediments strongly exceed 1 bar of partial pressure in cores from Peru margin Sites 1227, 
B.B. JøRGENSEN ET AL.

1229 , and 1230 . Consequently, the supersaturated methane formed gas voids in the sediment cores upon retrieval and some of the gas was lost. In order to retain the gas and obtain realistic concentration data, a pressure core sampler (PCS) was used successfully for coring at selected depths at Site 1230, which has very high in situ methane concentrations and also methane clathrates (Dickens et al., 2003). Methane concentrations as high as $959 \mathrm{mmol} / \mathrm{kg}$ were measured at $150 \mathrm{mbsf}$, the greatest depth sampled using the PCS. Measuring methane in samples collected using the PCS requires that the gas pressure be gradually released from the core and the volume of released gas measured at $1 \mathrm{bar}$.

As PCS operations are rather time consuming, an independent approach for determining high methane concentrations was tested during Leg 201 (Spivack et al., this volume). The method is based on immediate sampling of gas from voids within the decompressed core liner and simultaneous measurement of $\mathrm{CH}_{4}, \mathrm{~N}_{2}$, and $\mathrm{Ar}$ in the collected gas. As in situ concentrations of the conservative gases, $\mathrm{N}_{2}$ and $\mathrm{Ar}$, can be estimated from their environmental concentrations and solubilities, the ratio of $\mathrm{CH}_{4}: \mathrm{N}_{2}$ or $\mathrm{CH}_{4}: \mathrm{Ar}$ can be used to backcalculate the in situ partial pressure of $\mathrm{CH}_{4}$. This method allows calculation of in situ methane concentrations in sediment obtained by normal coring operations with the advanced piston corer (APC). Preliminary testing of the method provided concentrations of several hundred millimol $\mathrm{CH}_{4}$ per kilogram of sediment, consistent with data from PCS cores.

During core retrieval, piston cores that contain high concentrations of gas and gas hydrates undergo distinct changes in physical properties that can be monitored and thereby provide information about the gas properties. A temperature, pressure, and conductivity (TPC) tool mounted at the face of the standard ODP APC was successfully tested at Site 1226 (Ussler et al., this volume). Future applications of this tool at gas hydrate sites will show how ascent curves of TPC data may be used to interpret gas geochemistry.

\section{Nitrogen Transformations}

Organic matter in deep subsurface sediments reflects mineralization that has taken place over thousands or millions of years during burial since the organic material was originally deposited. The general changes in structure and composition with depth and age is overprinted by chemical alterations of the organic matter and by synthesis of new biomass of deep biosphere prokaryotes. Because of the extremely low energy supply and slow growth, growth yield and thus biomass production are expectedly only a small fraction of the organic matter turned over. Because the deposition rate of organic matter to the seafloor may have changed considerably over the millions of years during which burial took place, it is difficult to backcalculate the cumulative amount of organic degradation since the time of burial. Prokopenko et al. (this volume) assumed for Peru Trench Site 1230 steady-state conditions of sedimentation, burial, and diagenesis over the last $>1 \mathrm{~m}$.y. in order to calculate the amount of particulate organic nitrogen (PON) that had degraded to ammonium over that time window. They modeled the modern pore water profile of ammonium and arrived at the very plausible conclusion that $35 \%-42 \%$ of PON had been ammonified. The produced ammonium is isotopically very similar to the PON, on average only $0.7 \%$ enriched in the lighter isotope, ${ }^{14} \mathrm{~N}$, over the heavier isotope, ${ }^{15} \mathrm{~N}$. 
B.B. JøRGENSEN ET AL.

A similar backcalculation of organic mineralization for Peru shelf sediments is complicated by several factors. The influx of organic matter has varied significantly over glacial-interglacial cycles, presumably due to stronger upwelling and thus higher phytoplankton productivity in interglacial periods (Altabet et al., 1995; Ganeshram et al., 1995). Sediment organic carbon on the shelf originates from both marine and terrestrial sources, which have different carbon and nitrogen isotopic compositions; terrestrial organic nitrogen is isotopically lighter than the marine source. Prokopenko et al. (this volume) modeled sedimentary total organic nitrogen (TON) and ammonium concentrations and their N isotopic compositions for Site 1227 under both steady-state and nonsteady-state assumptions. The goal was to understand controls on diagenesis and diffusion transport in relation to the Holocene-Pleistocene history of deposition and mineralization. The results of their very innovative modeling efforts demonstrate the complexity of the nitrogen cycle and its geological evolution but also offer mechanisms to explain observed geochemical and isotopic data. It appears likely that a pulse of marine organic matter with $\delta^{15} \mathrm{~N}$ of $8 \% 0-10 \%$ deposited during the present interglacial is currently being degraded at a relatively high rate, thus releasing ammonium that is enriched in ${ }^{15} \mathrm{~N}$ relative to underlying residual bulk organic nitrogen that has $\delta^{15} \mathrm{~N}$ of $\sim 3 \%$. Through diffusional exchange, this isotopically heavy ammonium is currently affecting the $\delta^{15} \mathrm{~N}$ of ammonium in Pleistocene-Pliocene subsurface sediment at 10-35 mbsf, below which the signal is diluted by the pool of ammonium that diffuses upward, with $\delta^{15} \mathrm{~N}$ of $5 \%$, from the underlying Miocene brine. These results thus provide interesting information about progressing organic mineralization over geologic time.

\section{Mineralization Processes}

A broad spectrum of biogeochemical processes associated with microbial degradation of buried organic matter and transformations of gases, inorganic ions, and mineral phases was studied in sediment cores of Leg 201. Shipboard chemical analyses focused primarily on pore water species that were sampled at high depth resolution at all sites drilled. These data were published in the Leg 201 Initial Reports volume (D'Hondt, Jørgensen, Miller, et al., 2003). During the leg, only a few cations with particular relevance to the main objectives of the cruise were analyzed routinely $\left(\mathrm{Fe}^{2+}, \mathrm{Mn}^{2+}, \mathrm{Ba}^{2+}\right.$, and, partly, $\left.\mathrm{Sr}^{2+}\right)$. Other major cations $\left(\mathrm{Na}^{+}, \mathrm{K}^{+}, \mathrm{Ca}^{2+}, \mathrm{Mg}^{2+}\right.$, and $\left.\mathrm{Sr}^{2+}\right)$ were analyzed postcruise by inductively coupled plasma-atomic emission spectroscopy (ICP-AES) (Donohue et al., this volume). Whereas concentrations of these cations generally show only small variations with depth at the open Pacific sites, a strong and consistent trend of increasing concentrations with depth is observed on the Peru shelf as the result of brine at depth (Kastner et al., 1990; D'Hondt, Jørgensen, Miller, et al., 2003).

Pore water profiles of the main substrates and products of microbial processes provide information on progressing mineralization of organic material and biological energy metabolism. D'Hondt et al. (2004) used a biogeochemical flux model to calculate net reduction rates of nitrate, oxidized metals, and sulfate based on pore water concentrations of nitrate, manganese, iron, sulfate, and sulfide. At the ocean-margin sites and the most active open-ocean site, sulfate reduction is overall the dominant mineralization pathway. At the lowest-activity open-ocean Site 1231, sulfate reduction is marginal and organic carbon mineraliza- 
B.B. JøRGENSEN ET AL.

tion is mainly driven by reduction of manganese and iron. Nitrate reduction is detectable only at low-activity Sites 1225 and 1231. Interestingly, at Sites 1225 and 1231 nitrate penetrated into the sediment column not only from seawater above but also from fluids seeping through basaltic crust below.

Rates of biogeochemical processes were also measured experimentally in retrieved core samples by incubation with radiolabeled substrates. Tracers included ${ }^{35} \mathrm{~S}$-labeled sulfate and ${ }^{14} \mathrm{C}$-labeled bicarbonate or acetate, and the results provide information on gross rates of sulfate reduction and methanogenesis in deep subsurface sediments. As an example, results of such sulfate reduction measurements from Site 1226 are presented in Figure F2A. Reduction rates drop steeply over the uppermost $10 \mathrm{~m}$ from $20-30 \mathrm{pmol} / \mathrm{cm}^{3} / \mathrm{d}$ at the sediment surface to $<1$ $\mathrm{pmol} / \mathrm{cm}^{3} / \mathrm{d}$. Below $20 \mathrm{mbsf}$ rates are mostly below the detection limit of $0.3 \mathrm{pmol} / \mathrm{cm}^{3} / \mathrm{d}$. This limit is set by the minimum of radiolabeled sulfide that must be formed during incubation experiments to be distinguishable from background in the liquid scintillation counter. Detectability of sulfate reduction was optimized by long incubations of several weeks and by improved separation of radioactive sulfide and sulfate after incubation (Kallmeyer et al., 2004). The sulfate reduction data above background in subsurface sediments are very scattered; there is distinct clustering of detectable rates in the depth interval 280-310 mbsf. The sulfate profile through the entire sediment column at Site 1226 shows a subsurface decrease from $29 \mathrm{mM}$ to a minimum of $\sim 21$ $\mathrm{mM}$ at mid-depth (Fig. F2B). Below that, sulfate concentrations again increase toward seawater value near basement. Methane is detectable throughout the sulfate zone, although at very low concentrations of 0 $3 \mu \mathrm{M}$ (Fig. F2B). The enhanced sulfate reduction rates measured at 280310 mbsf coincide with a distinct maximum in dissolved manganese and thus in manganese reduction (Fig. F2C). These increased sulfate reduction rates also coincide with a minimum in color reflectance, possibly due to light-absorbing manganese oxides (D'Hondt, Jørgensen, Milller, et al., 2003). Sediment at this depth was deposited during the Miocene "carbonate crash" 10 m.y. ago, at a time of low organic deposition and thus more efficient burial of manganese. This coincidence of enhanced mineralization rates shows that modern subsurface activity is related to past oceanographic conditions at the time of sediment deposition. The reasons for enhanced sulfate reduction in the manganeserich zone are, however, not clear. $\mathrm{H}_{2} \mathrm{~S}$ concentrations show a broad peak at sediment depths (20-280 mbsf) where there is little sulfate reduction (Fig. F2C). Manganese distribution clearly exerts an equally important role on free sulfide distribution, as does the rate of $\mathrm{H}_{2} \mathrm{~S}$ production.

Based on the pore water sulfate profile at Site 1226, D'Hondt et al. (2004) modeled the sulfate flux, from which a mean sulfate reduction rate of $0.02 \mathrm{pmol} / \mathrm{cm}^{3} / \mathrm{d}$ can be calculated for the upper $200 \mathrm{mbsf}$ (see below). This modeled rate is an order of magnitude below the minimum detection limit for experimental sulfate reduction measurements and explains why below 10 mbsf most data fall below detection (Fig. F2A). It should be noted that the model approach provides net sulfate reduction, whereas experimental rate measurements provide gross sulfate reduction. Generally, differences between the two may be caused by (a) net rates underestimating sulfate reduction due to reoxidation of sulfide to sulfate in the subsurface sediment or (b) gross rates overestimating sulfate reduction because of a stimulation of microbial activity by coring and sample handling.
F2. Radiotracer experiments and pore water data, Site 1226, p. 40.

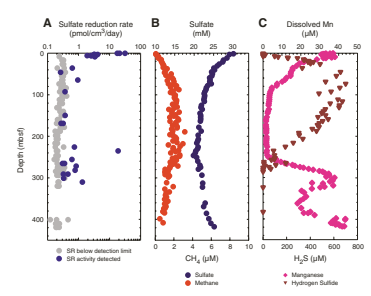


B.B. JøRGENSEN ET AL.

\section{Stable Isotope Effects of Bacterial Sulfate Reduction}

Pore water sulfate profiles clearly show the very different levels of microbial activity in the subsurface sediments of the open-ocean and ocean-margin sites. As the temperatures of all sediments drilled $\left(1^{\circ}-\right.$ $26^{\circ} \mathrm{C}$ ) are within the normal range of psychrophilic or mesophilic microorganisms, no thermochemical sulfate reduction takes place. Microbial sulfate reduction is associated with a kinetic isotope effect in which sulfate with the lighter isotope, ${ }^{32} \mathrm{~S}$, is reduced faster than sulfate with the heavy isotope, ${ }^{34} \mathrm{~S}$ (Kaplan and Rittenberg, 1964; Chambers and Trudinger, 1979). Seawater sulfate has had a nearly constant isotopic composition of $\delta^{34} \mathrm{~S}=21 \%$ (relative to the international Vienna Canyon Diablo Troilite [V-CDT] standard over the past 50 m.y. (Paytan et al., 1998). Biological sulfur fractionation during sulfate reduction is $15 \% 0-40 \%$ in pure cultures of sulfate-reducing bacteria, whereas in modern marine sediments the isotopic difference between sulfate and sulfide is generally somewhat larger, 30\%-60\%o (Canfield, 2001a, 2001b) but may reach as high as $>70 \%$ (Wortmann et al., 2001; Rudnicki et al., 2001). Some of the earliest evidence that sulfate reduction takes place through viable microorganisms in deep subsurface sediments was in fact derived from stable sulfur isotope studies that showed biological isotope fractionation (Zak et al., 1980).

The sulfur isotopic compositions of sulfate from Leg 201 sites clearly show the effect of biological isotope fractionation associated with microbial sulfate reduction (Böttcher et al., this volume). The deviation in isotopic composition relative to $\delta^{34} \mathrm{~S}$ in seawater varies in proportion to the degree of sulfate depletion: no deviation is detectable at Peru Basin Site 1231, where sulfate concentrations remain nearly constant through the entire sediment column, open Pacific Sites 1225 and 1226 show modest deviation, and strongest deviation, $\delta^{34} \mathrm{~S}$ of as much as $80 \%$ û $90 \%$, occurs at the Peru margin sites where sulfate is completely consumed at depth. Using a mathematical model of Claypool (2004) that takes both sulfate reduction and diffusive exchange into account, Böttcher et al. (this volume) calculated sulfur isotope fractionations by microbial sulfate reduction of $14 \% 0-40 \%$ (i.e., in the lower range for modern marine sediments).

Seawater sulfate has isotopic diversity not only in sulfur but also in oxygen. During sulfate reduction in laboratory cultures or in marine sediments residual sulfate becomes enriched in the heavy isotope ${ }^{18} \mathrm{O}$ (Mitzutani and Rafter, 1973; Fritz et al., 1989; Böttcher et al., 1998; Aharon and $\mathrm{Fu}, 2000)$. In contrast to the kinetic isotope effect for sulfur fractionation by microbial sulfate reduction, the primary mechanism of oxygen isotope fractionation is thought to be an intracellular isotope exchange between water and sulfur intermediates formed during dissimilatory sulfate reduction. In marine sediments this leads to partial oxygen isotope equilibration between sulfate and water molecules in the pore fluid. Complete oxygen isotope equilibration would imply enrichment of ${ }^{18} \mathrm{O}$ in pore water sulfate from $\delta^{18} \mathrm{O}$ of $9.5 \%$ in seawater sulfate to $>30 \%$ (relative to Vienna standard mean ocean water [VSMOV]) (Böttcher et al., 1998). An alternative pathway of ${ }^{18} \mathrm{O}$ enrichment in pore water sulfate could be a reoxidation of sulfide by Mn(IV) or $\mathrm{Fe}(\mathrm{III})$, possibly via disproportionation reactions, whereby the produced sulfate incorporates pore water oxygen (Böttcher et al., 2001).

Blake et al. (this volume) analyzed oxygen isotope compositions of pore water sulfates from the open Pacific sites of Leg 201. The results demonstrate a clear relationship between degree of microbial sulfate re- 
B.B. JøRGENSEN ET AL.

duction and oxygen isotopic enrichment in residual pore water sulfate. $\delta^{18} \mathrm{O}-\mathrm{SO}_{4}{ }^{2-}$ does deviate from seawater value at Site 1231 , where sulfate depletion is minimal, whereas pore water sulfate is $10 \% 0-20 \%$ enriched in ${ }^{18} \mathrm{O}$ at Sites 1225 and 1226 . Surprisingly, calculated ${ }^{18} \mathrm{O}$ isotope enrichment for Sites 1225 and 1226 ranges from 42\%o to 79\%o, which is several-fold higher than the highest fractionations yet recorded in laboratory cultures of sulfate-reducing bacteria. The cause of this strong fractionation is not known but may be an unexpectedly high degree of intracellular equilibration with oxygen from water during extremely low cellular sulfate reduction rates. Additionally, it could be a result of sulfide oxidation and sulfur disproportionation, whereby the produced sulfate incorporates oxygen from pore water (Böttcher et al., 1998, 2001). The maximum $\delta^{18} \mathrm{O}-\mathrm{SO}_{4}{ }^{2-}$ enrichments observed remain below the expected value for complete isotope exchange equilibrium with ambient pore water.

As an example of these isotopic fractionations and their relation to sediment diagenesis, Figure F3 shows data on pore water chemistry and $\delta^{34} \mathrm{~S}$ and $\delta^{18} \mathrm{O}$ of sulfate from relatively organic rich eastern equatorial Pacific Site 1226. Dissolved inorganic carbon (DIC) and ammonium are produced by mineralization of sediment organic matter. Maximum concentrations are reached below 50-100 mbsf. Toward the crust that underlies the 418-m sediment column, concentrations decrease again as DIC and ammonium diffuse down into crustal fluid of near-seawater composition. The ammonium maximum in the upper part of the sediment column occurs where turnover of organic nitrogen is higher than deeper in the sediment. This peak coincides with a peak in $\mathrm{H}_{2} \mathrm{~S}$ produced from sulfate reduction. Sulfate concentrations decrease from the seawater value of $29 \mathrm{mM}$ to a minimum of $21 \mathrm{mM}$ at mid-depth (200$300 \mathrm{mbsf}$ ), whereas $\delta^{34} \mathrm{~S}-\mathrm{SO}_{4}{ }^{2-}$ increases to a maximum of $37 \%$. Toward the basaltic crust sulfate concentrations increase again to a near-seawater value of $26 \mathrm{mM}$ while $\delta^{34} \mathrm{~S}_{-} \mathrm{SO}_{4}{ }^{2-}$ similarly decreases to $25 \%$. This trend toward seawater values at the crust shows that fluid flow through basalt has $\delta^{34} \mathrm{~S}_{-} \mathrm{SO}_{4}{ }^{2-}$ similar to seawater, which indicates that crustal sulfate has not been significantly affected by bacterial reduction along its flow path. These interpretations of sulfur isotope distributions are confirmed by $\delta^{18} \mathrm{O}-\mathrm{SO}_{4}{ }^{2-}$, which reaches $+28 \%$ at $70-140 \mathrm{mbsf}$ and drops again to near-seawater values at the bottom of the sediment column (Fig. F3). On the Peru shelf, in contrast, sulfate diffusing upward from the underlying Miocene brine is enriched in ${ }^{34} \mathrm{~S}$ relative to seawater. This deep sulfate source has apparently already been modified by microbial sulfate reduction, probably at the time of brine formation by evaporation.

\section{MICROBIOLOGY}

Over the last two decades, studies of the deep subseafloor biosphere have mostly focused on the magnitude of microbial populations as measured by total microscopic cell counts (Parkes et al., 1994, 2000). Such data have revealed that the subsurface biosphere is the largest reservoir of biomass on Earth (Whitman et al., 1998). Yet, only few studies have addressed the structure, diversity, and function of subsurface microbial communities. It was therefore one of the primary objectives of Leg 201 to explore physiological and phylogenetic types of bacteria, both with respect to overall diversity and to dominant populations.
F3. Isotope variations in pore water sulfate, Site 1226, p. 41.

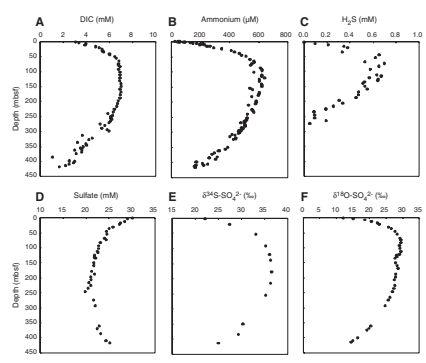


B.B. JøRGENSEN ET AL.

Discrimination between active and dormant organisms was a particular challenge because only metabolically active cells currently contribute to biogeochemical processes.

During Leg 201 and during subsequent extensive laboratory studies a range of approaches was used to quantify bacterial abundance, diversity, and activity. These approaches have included

1. Total microscopic cell counts;

2. Cultivation methods, mostly starting with the most probable number (MPN) technique;

3. DNA- and RNA-based techniques, in particular the establishment of sequence information;

4. Key genes and the use of fluorescence in situ hybridization (FISH); and

5. Radiotracer and stable isotope tracer experiments on specific microbial processes.

Because successful application of all these approaches depends fully on recovery of deep sediment samples uncontaminated by microorganisms from the surface world, tests for contamination were conducted during the entire coring operation and during sampling for microbiology.

\section{Core and Sample Handling and Contamination Tests}

The sedimentary environment in the deep subseafloor has experienced highly constant conditions for millions of years. Prokaryotic organisms that inhabit this stable ecosystem are therefore expected to be sensitive to chemical and physical changes induced by core sampling and handling, in particular to changes in oxygen, temperature, and pressure. While drilling in the tropics during Leg 201, warming of cores during retrieval through warm surface waters and during handling on deck was of major concern. Another concern was release of hydrostatic pressure, $>50 \mathrm{MPa}$, in cores retrieved from the maximal water depth $(5086 \mathrm{~m})$ of Site 1230 in the Peru Trench. The technology for subsampling cores without decompression was, however, not yet available at the time of Leg 201.

Deep biosphere research requires that recovered cores are suitable for microbiological study and that recovered core material is not contaminated with microbes from drilling fluid. Standard ODP coring and sampling procedures were therefore modified in order to minimize changes after coring (Shipboard Scientific Party, 2003a). Intermittent warming was reduced by immediately transferring core sections to a cold room, where all subsequent microbiological sampling was done. Exposure to oxygen and to contaminating bacteria was reduced by maintaining core segments as whole-round cores until sampling. Core segments were cut under aseptic and anoxic conditions, and only sediment from the uncontaminated center of cores was used for enumeration, isolation, and identification of microorganisms or for activity analyses and experiments. The new core handling procedures applied during Leg 201 caused a delay in coring and a loss of stratigraphic continuity in archived cores, yet it was an absolute prerequisite for obtaining highquality material for microbiological studies. However, each site that was drilled during this leg had been drilled and described before according to standard ODP procedures (during DSDP Leg 34, Peru margin ODP Leg 112, and equatorial Pacific ODP Leg 138) (Fig. F1). 
B.B. JøRGENSEN ET AL.

An indication of whether potential contamination with microorganisms from the surface world has taken place may be obtained by comparing the diversity of sediment populations with those in the seawater applied for drilling. Such a comparison, based on $16 \mathrm{~S}$ ribosomal RNA (rRNA) gene sequencing and culturing methods, have been used to argue against contamination of samples taken from deep granitic aquifers (Pedersen et al., 1997). During Leg 201, more direct contamination tests were made in all samples used for microbiological studies and for activity measurements in order to check for potential introduction of liquid or cells from the outside. Two types of contamination tracers were applied during drilling: (a) a water-soluble perfluorocarbon tracer (PFT) and (b) fluorescent microspheres (Smith et al., 2000a, 2000b; House et al., 2003). The fluorocarbon (perfluoromethylcyclohexane, $\mathrm{C}_{6} \mathrm{~F}_{11} \mathrm{CF}_{3}$ ) was continuously fed into the drilling fluid at tracer concentration and could subsequently be detected at high sensitivity in core samples potentially affected by this diffusible contaminant. The fluorescent microspheres were of similar size $(0.5 \mu \mathrm{m})$ as indigenous microorganisms $(0.2-1.3 \mu \mathrm{m})$ and tested potential penetration of microbial cells from the outside into the core samples. About $10^{11}$ microspheres were injected at the tip of the APC as it released so that the core surface became smeared with this particulate tracer. The principal results of these two contamination tests were that the applied APC coring and handling procedures can produce sediment samples with nondetectable particle contamination and with dissolved tracer contamination corresponding to $<0.1 \mu \mathrm{L}$ seawater or $<50$ prokaryotes/g sediment. The latter is a maximum estimate, as it assumes that bacterial cells can follow diffusion of PFT tracer into the cores. The results also show that extended core barrel (XCB) coring generally produces contaminated samples and that continuous and scrupulous contamination tests are a prerequisite for obtaining microbiological samples with minimal risk of contamination. As phylogenetic identification of subseafloor communities develops in the future it may become possible to detect contaminating cell types from the surface and apply this as an additional test of potential contamination.

\section{Total Cell Counts}

The most widely used procedure to count prokaryotic cells in marine sediments is based on staining with a fluorescent nucleic acid stain followed by microscopic counts of fluorescent cells. Such counts using the stain acridine orange have been made on a wide range of ODP sediment cores, including cores from the Peru margin and the equatorial Pacific Ocean (Parkes et al., 1994). Data from these authors demonstrate an exponential decrease of microbial cell densities with depth, from $\sim 10^{8}$ cells $/ \mathrm{cm}^{3}$ at the sediment surface to two orders of magnitude lower counts below 100 mbsf. Minimum cell densities of $10^{4}-10^{5}$ cells $/ \mathrm{cm}^{3}$ were consistently detected even in the deepest sediments sampled at 800 mbsf.

The acridine orange direct count (AODC) method was applied at all sites of Leg 201 and yielded cell densities that are consistent with the general trend of the global data set of Parkes et al. (2000). Yet, cell numbers also demonstrate deviations that could be interpreted in terms of changing past oceanographic conditions at the time of sedimentation or in terms of the present geochemical zonation of the sediment column. Figure F4 shows cell enumeration data from all Leg 201 sites com-

F4. Cell enumeration data, p. 42.

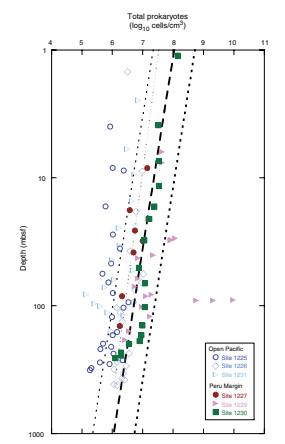


B.B. JøRGENSEN ET AL.

pared to previously censused sites. The figure includes data from $1 \mathrm{mbsf}$ to the deepest sediment cored. Cell densities from open-ocean sites generally fall below the geometric mean of the global data set, whereas cell densities from the Peru margin fall on or above the mean. This trend is in accordance with previous observations that show greater bacterial populations in ocean-margin sites than in open-ocean sites (Parkes et al., 2000) and also large populations associated with gas hydrate sites (Wellsbury et al., 2000; Cragg et al., 1996).

These results lead to several important conclusions. The community size in different oceanic settings reflects the burial rate of organic carbon, which is the main energy source for the prokaryotic cells. Thus, cell densities are highest where concentrations of metabolic products (DIC, $\mathrm{CH}_{4}$, and $\mathrm{NH}_{4}{ }^{+}$) and net rates of sulfate and iron reduction are highest. Some of the highest cell densities ever observed beneath the seafloor were detected in sediments recovered from the Peru shelf. In contrast, the open-ocean sites contain some of the lowest average cell densities ever observed in deep-sea sediments (D'Hondt et al., 2004). The community size decreases by several orders of magnitude between the surface sediment and the deep subsurface, yet cell density rarely drops below the detection limit of $10^{4}-10^{5} \mathrm{cells} / \mathrm{cm}^{3}$. Even in the deepest sediment from 420 mbsf (Site 1226) or in the oldest sediment of $\sim 35$ Ma (Site 1231), morphologically intact cells with stainable DNA could be counted.

It is striking that cell numbers from the continental shelf sites fall closer to the geometric mean of the global data set than do cell numbers from the open-ocean sites. This indicates that the data set may be skewed toward the ocean margin relative to the global distribution of sediments. In fact, ODP coring sites are far more abundant along the ocean margins than in the central gyres of the open ocean. This means that global extrapolation of total subsurface bacterial biomass is probably overestimated and should be corrected to take into account the areal coverage of sediments with lower cell densities. Due to the sparsity of data for open-ocean and low-productivity provinces, such a geographically weighted extrapolation remains uncertain and calls for further cell enumerations in poorly represented ocean regions.

\section{Cultivation of Prokaryotes}

It is somewhat discouraging to realize that most bacteria that live in natural environments have so far resisted all efforts to bring them into laboratory culture. This may, at least in part, be explained by differences in environmental conditions offered during cultivation in defined media relative to the complex conditions of the natural habitat. In the habitat, energy substrates are generally present in very low concentrations, but they are steadily produced. In cultivation media, the energy substrate is present in high concentration from the start in order to support a significant number of cell divisions. The cultivation media thereby select for opportunistic organisms able to grow relatively fast under rich substrate conditions that they would never encounter in the deep subsurface.

A most striking quality of the deep biosphere is the extremely slow growth of organisms, with estimated mean generation times of many years (Whitman et al., 1998; Schippers et al., 2005). It has not yet been possible to measure such low growth rates by direct approaches, so current estimates are based on a comparison of total population size with potential metabolic rates, calculated from chemical data or from sensi- 
B.B. JøRGENSEN ET AL.

tive radiotracer experiments ( $\mathrm{D}^{\prime}$ Hondt et al., 2002). The exceedingly slow growth of subseafloor populations may help explain why the number of successful cultivations and isolations has been quite limited (e.g., Bale et al., 1997; Barnes et al., 1998; Inagaki et al., 2003; Mikucki et al., 2003). It also raises the question to what extent physiology and growth characteristics of isolates that have indeed been obtained from deep sediment cores are representative of those deep subseafloor populations. Although this question is difficult to answer at the present time, isolation and characterization of indigenous bacteria from ODP core material does provide useful information for at least part of the microbial populations.

A large number of cultivation experiments were initiated during Leg 201 in order to study taxonomic and physiological diversity of subsurface prokaryotic communities. These cultivation experiments used many different selective media for enrichments in order to target a broad spectrum of physiological types with respect to energy metabolism and adaptation to the physical-chemical environment. Some cultivations focused on heterotrophs that could use different electron acceptors for respiration or that could degrade different monomeric or polymeric carbon sources. Other cultivations focused on methanogens and acetogens or on fermenting or spore-forming prokaryotes. Still others targeted chemoautotrophic prokaryotes utilizing different combinations of inorganic redox couples as electron donors and acceptors. Incubation conditions were chosen to cover a broad spectrum of adaptations to $\mathrm{pH}$, salinity, or temperature (psychrophiles, mesophiles, and thermophiles, respectively).

Sediment samples were homogenized into slurries using cultivation media and subsequently diluted in tenfold steps in media that could potentially support growth of specific physiological types of prokaryotes. By scoring the highest dilution steps with positive growth, the MPN of viable cells in the original samples could be estimated according to a standard statistical procedure (American Public Health Association, 1989). Such MPN counts typically provide only a minimum estimate of true numbers of organisms that are viable in situ because many prokaryotes (or even the vast majority) are not cultivable with currently available methods. Shipboard MPN cultivations also served as starting material for later enrichments and isolations of the prokaryotes in shore-based laboratories. Isolation of prokaryotes from the highest dilutions with positive growth maximizes the chance of ultimately cultivating organisms that are quantitatively dominant and that are, therefore, biogeochemically important.

Bacteria were successfully cultured and isolated from multiple depths at every site. The highest cultivation success was obtained at Peru margin Site 1229, where MPN counts reached as high as 48,000 cells $/ \mathrm{cm}^{3}$ (H. Cypionka, pers. comm., 2005). This corresponds to a counting efficiency of up to $0.1 \%$ of the total cell counts obtained by AODC (D'Hondt et al., 2004). Such counting efficiency is not significantly lower than MPN efficiencies obtained in marine surface sediments. It was important by these counting and cultivation experiments that the media had low concentrations $(>100 \mu \mathrm{M})$ of mixed substrates. Such low-nutrient media have been found to yield higher numbers of cultured bacteria and also higher diversity (e.g., Kaeberlein et al., 2002; Zengler et al., 2002). In fact, bacteria adapted to low substrate concentration may be irreversibly damaged by exposure to high substrate concentrations (Barer and Harwood, 1999). Isolations further- 
B.B. JøRGENSEN ET AL.

more utilized mixed substrates and potential trace compounds by adding sediment extract or reducing agents to the media.

Cultivation results indicate that living bacteria are present throughout the entire range of subseafloor depths sampled (D'Hondt et al., 2004). Thus, at open Pacific Sites 1225 and 1226, bacteria could be isolated from the sediment surface to the greatest depth cored at 307 or 420 mbsf, corresponding to sediment ages of $\sim 10$ or $15 \mathrm{Ma}$, respectively. A total of 172 pure cultures were isolated by the microbiology group at Oldenburg University in Germany (H. Cypionka and B. Engelen, pers. comm., 2005). Interestingly, a majority of the strains turned out to be facultative aerobes, even though they were isolated from anoxic environments using strict anaerobic technique. There is presently no clear explanation for this observation. The 16S rRNA genes were analyzed for all the isolates and show that these represent a broad spectrum within the bacterial kingdom. The isolates belong to the following six lineages: $\alpha-, \gamma$-, and $\delta$ Proteobacteria, Firmicutes, Actinobacteria, and Bacteroidetes. About 40\% of all the isolates could be assigned to the spore-forming genus Bacillus. Most of the isolates are related to known marine organisms. Others are distant from known organisms and will be assigned to new genera. It was an interesting observation that the 16S gene of one isolate from openocean Site 1225 differed from its nearest known relative within Bacteroidetes by as much as $14 \%$. It thus appears to represent a new genus of a distinct phylogenetic lineage.

Whereas all of those isolates grow in the mesophilic temperature range, Biddle et al. (this volume) attempted to isolate psychrophilic methanogens and heterotrophic bacteria by incubating sediment at $2^{\circ}$ or $10^{\circ} \mathrm{C}$. Samples were taken from Site 1230 in the Peru Trench at 5300 $\mathrm{m}$ water depth where the sediment is rich in organic matter and gas hydrates occur below the 9-m-deep sulfate zone. One of the objectives was to determine whether metabolically active methanogens are present in the gas hydrate zone. Several previous studies have searched for archaeal populations in subseafloor sediment but did not find 16S rRNA genes of methanogens in their libraries (Biddle et al., 1999; Marchesi et al., 2001; Mikucki et al., 2003; Newberry et al., 2004). More recent studies, however, have indeed found evidence for methanogens in subseafloor sediment by using specific 16S rRNA or functional gene (methyl coenzyme-M reductase; $m c r A$ ) primers (Marchesi et al., 2001; Newberry et al., 2004; Sørensen et al., 2004; Parkes et al., 2005; Inagaki et al., 2006). A mesophilic methanogen species designated Methanoculleus submarinus was recently isolated from 247 mbsf in the Nankai Trough (Mikucki et al., 2003). Although a few psychrophilic methanogens are in pure culture, none are from marine subsurface sediment (Chong et al., 2002; Franzmann et al., 1997). Interestingly, Biddle et al. (this volume) found during initial enrichments in aerobic medium an archaeal polymerase chain reaction (PCR) product by ribosomal intergenic spacer analysis (RISA) fingerprinting that belongs to a group of uncultivated benthic Crenarchaea (Ventriani et al., 1999; Bowman and McCuaig, 2003). The basic physiology of this group remains unknown, and further attempts of isolation were not successful. The group appears commonly in the 16S rRNA gene libraries obtained from Leg 201 sites (Sørensen et al., 2004; Inagaki et al., 2006).

All the main substrates for methanogenesis were applied in the lowtemperature enrichments by Biddle et al. (this volume), yet methanogens could not be detected, even after 2 yr of incubation. Upon enrichment in marine broth medium, however, several isolates of heterotrophic bacteria were obtained that are moderately psychrophilic 
B.B. JøRGENSEN ET AL.

in their temperature growth range. These represent the genera Photobacterium, Shewanella, Halomonas, and Vibrio. These produce extracellular lytic enzymes, protease or esterase, that are active at low temperature and may lyse macromolecular organic compounds such as proteins or lipids (Boetius and Lochte, 1994; Luna et al., 2004). The Photobacterium isolate has high $16 \mathrm{~S}$ rRNA sequence similarity to the previously described P. profundum (Nogi et al., 1998) and similarly shows adaptation to high hydrostatic pressure by growing at $40 \mathrm{MPa}$ (the highest pressure tested), corresponding to $4000 \mathrm{~m}$ water depth (Biddle et al., this volume).

At the other end of the temperature scale, a new group of thermophilic bacteria was isolated from sediments of the Peru margin. Altogether 10 thermophilic isolates were obtained from sediment cores taken from 1-2 mbsf at in situ temperatures ranging from $2^{\circ}$ to $12^{\circ} \mathrm{C}$ (Lee et al., 2005). Attempts to isolate them from greater sediment depths were not successful. The bacteria are anaerobic heterotrophs belonging to family Thermoanaerobacteriaceae and have growth optimum temperatures of $64^{\circ}-68^{\circ} \mathrm{C}$. A novel genus, Thermosediminibacter, was proposed for the described isolates. Given the high temperature required for their growth $\left(>40^{\circ}-50^{\circ} \mathrm{C}\right)$ and their apparent absence from deeper, older sediments, the occurrence of these bacteria in shallow and relatively cold shelf sediments can possibly be explained by their dispersal through the ocean from hotter environments, sedimentation onto the seafloor, and maintenance of viability for the few thousands or tens of thousands of years represented by the uppermost 1-2 $\mathrm{m}$ of sediment at these sites.

Isolation of novel genera of bacteria in combination with the discovery of unknown deeply rooted archaeal $16 \mathrm{~S}$ gene sequences shows that previously undiscovered prokaryotes exist in deep subseafloor sediments of the ocean. It remains an important task of future Integrated Ocean Drilling Program (IODP) research to develop further approaches for cultivating of these unknown microorganisms and for studying their physiological and biochemical adaptation to their special environment.

\section{DNA- or RNA-Based Identification}

Since cultivation-based analyses of subseafloor microbial populations are very time consuming in comparison to the number of successful isolations, cultivation-independent molecular analyses have become an indispensable part of all population studies. Molecular phylogenetic analyses are generally based on 16S rRNA gene sequences in DNA extracted from the environment. The ribosome is involved in translation of messenger RNA into proteins and is therefore a universal component of all living cells. The $16 \mathrm{~S}$ rRNA gene has $\sim 1500$ base pairs, the sequence of which has remained sufficiently conserved throughout 3.5 billion years of prokaryotic evolution to provide information on evolutionary ancestry and relationship. Based on rRNA, life is divided into the three domains of Bacteria, Archaea, and Eukarya (Woese et al., 1990). Analysis of $16 \mathrm{~S}$ rRNA sequences provides an excellent possibility to characterize mixed microbial communities in natural environments without cultivation. The results have shown that prokaryotic diversity is much greater than indicated by previous results from half a century of cultivation and isolation. The results have also revealed numerous entirely new and so-far uncultivated phylogenetic lineages of prokaryotes (e.g., Barns et al., 1996; Hugenholtz et al., 1998). 
B.B. JøRGENSEN ET AL.

Close phylogenic relationship of novel 16S rRNA sequences to those of cultured microorganisms with known physiologies may in many cases provide an indication of the physiology of the uncultured prokaryotes. In other cases, however, such conclusions about metabolic function may be wrong and very misleading. It is therefore important to also search for gene sequences that encode for key enzymes of metabolic pathways. Such functional genes provide information on the physiological types of microorganisms present in subsurface sediments of different geochemical zones. By comparison with 16S rRNA data the molecular ecologist can thus combine information on the identity and function of complex microbial communities. Among the important key genes analyzed from Leg 201 samples are dissimilatory (bi)sulfite reductase $(d s r A B)$ and adenosine- 5 '-phosphosulfate (APS) of sulfate-reducing bacteria (Klein et al., 2001; Stahl et al., 2002) and mcrA of methanogenic archaea (Springer et al., 1995). Thus, Schippers and Neretin (in press) found the $d s r A$ gene to be abundant in sediments of the Peru margin with $10^{6}-10^{8}$ gene copies per $\mathrm{cm}^{3}$ in near-surface sediments and much lower numbers in the deep sediments. The depth gradients were steeper for the gene copy numbers than for numbers of total prokaryotes (AODC counts), which reflects the ongoing degradation of the high-molecular-weight DNA with sediment age and depth.

Results of sequencing surveys from Leg 201 samples have been reviewed by Teske (this volume), and only some selected aspects will be discussed here. Extensive 16S rRNA clone libraries are now available for open-ocean Site 1225, Peru shelf Site 1227, Peru Trench gas hydrate Site 1230, and Peru Basin Site 1231. These libraries provide rich information on the phylogenetic diversity of the deep subsurface biosphere in this part of the ocean. It was a striking observation that the 16S rRNA clone libraries are dominated by a large number of uncultured lineages of bacteria and archaea for which nothing or very little can be deduced in terms of their basic physiology and metabolism. For other lineages, the more or less close phylogenetic affiliations with cultured organisms of known physiology motivate conclusions about the metabolic function of the unknown organisms. Their presence in different geochemical zones, which offer different potential redox couples of organic and inorganic compounds to maintain energy metabolism, appears to be an important key to their functional role in the subsurface. Yet, the distribution of specific phylogenetic groups within different biogeochemical zones dominated by sulfate reduction, manganese reduction, methanogenesis, or anaerobic methane oxidation does not provide a pattern that can be interpreted well today. Surprisingly, $16 \mathrm{~S}$ rRNA genes representing known groups of sulfate-reducing bacteria of $\delta$-Proteobacteria or known lineages of methanogenic archaea are sparse in the clone libraries, even in sediment horizons where sulfate reduction or methanogenesis should dominate microbial processes according to pore water chemistry (Parkes et al., 2005). At Site 1230, Inagaki et al. (2006) found $\delta$-Proteobacteria to be more frequent in deep sulfate-free sediment than in the near-surface sulfate zone. The key gene of methanogenesis ( $\mathrm{mcr} A$ ) related to known groups of methanogens was detected in a number of samples, but their occurrence does not clearly mirror horizons with intensive methanogenesis (Parkes et al., 2005; Inagaki et al., 2006). Sequence information that couples the 16S rRNA gene with other functional genes specific for certain metabolic pathways will be needed in order to determine the relationship between prokaryotic diversity and function. Such coupled genomic information is still missing. 
B.B. JøRGENSEN ET AL.

In accordance with this limited possibility of functional interpretation, even for major phylogenetic lineages, the new groups have been given names that mostly reflect the environment of original discovery. Among the archaea, the Deep-Sea Archaeal Group (DSAG) was originally found at hydrothermal vent sites by Takai and Horikoshi (1999) and is widely represented in the deep subseafloor, including Leg 201 sites. As a notable exception, Site 1227 is dominated by other archaeal sequences currently positioned among the Miscellaneous Crenarchaeotal Group (MCG) and the South African Goldmine Euryarchaeotal Group (SAGMEG) (Inagaki et al., 2006). At Site 1229 the MCG totally dominates the clone library analyzed by Parkes et al. (2005) and Webster et al. (in press). They found only one sequence, within the methane zone of the sediment column, that could be related to methanogens. Although such differences in archaeal dominance are interesting, there is presently no consistent explanation for the observations.

Among the bacterial sequences, uncultured members of Planctomycetes and Chloroflexi are frequently encountered (Inagaki et al., 2006). At Site 1229, sequences of green nonsulfur bacteria (GNS) and $\gamma$ Proteobacteria are particularly dominant (Parkes et al., 2005). Webster et al. (2004) developed 16S rDNA targeted primers for PCR to search for a novel group of uncultured bacteria that had been detected repeatedly in samples from surface and deep marine sediments. They identified a deeply branching, monophyletic cluster, designated candidate division JS-1, named in recognition of the Japan Sea as the first reported source of these sequences (Rochelle et al., 1994). The group has no cultivated relatives and its physiology is unknown, apart from its expectedly anaerobic nature based on its consistent occurrence in anoxic sediments, including Peru margin Sites 1228 and 1229 at depths to 86 mbsf. The frequency of the different bacterial groups in deep subsurface clone libraries shows some consistencies with other oceanic regions. In deep sediments from the Sea of Okhotsk, $\gamma$-Proteobacteria were observed to dominate in some layers whereas GNS and JS1 bacteria dominate in others (Inagaki et al., 2003).

The above examples from Leg 201 show that it is possible to extract DNA from deep sediment cores and use this DNA to sequence 16S rRNA genes that can be aligned and positioned in the phylogenetic tree of modern bacteria or archaea. The presence of intact gene sequences is, however, not in itself a proof of viable cells but could represent fossil remains of prokaryotic organisms that lived during earlier geologic periods. Thus, Inagaki et al. (2001) observed that sequences related to thermophilic and halophilic archaea are the predominant components in Pleistocene subseafloor pelagic clays. They interpreted this as remnants of a community that was trapped in the sediments at a time when the site was surrounded by hydrothermal and geothermal environments. The organisms had thus been preserved since the time of deposition under cold conditions that might not have enabled growth. It should be noted, however, that although the sequences cluster with known modern thermophiles this does not exclude the possibility that the sequences originate from organisms able to live in the temperature regime prevailing in the sediment today.

In support of the preservation hypothesis, Inagaki et al. (2005) analyzed 16S rRNA sequence diversity in and around a marine black shale horizon of $\sim 100$ Ma age, originally deposited in the ocean during a major anoxic event and now situated in southern France. Within the shale, $\delta$-Proteobacteria sequences related to sulfate-reducing bacteria predominated, whereas sequences of $\gamma$-Proteobacteria dominate above 
and below the black shale. The recovered DNA signatures are consistent with the interpretation that the sequences are derived from past microbial communities buried in the subseafloor environment and preserved until the present. This has important potential implications. If such ancient sedimentary deposits can retain their genetic signals for many millions of years, then it may be possible to use such information to infer past geological conditions and microbial activities. Inagaki et al. (2005) coined the term "Paleome" for such a genetic record of past microbial communities.

Results obtained by Sørensen et al. (2004) from Site 1231 in the Peru Basin appear to contrast with this interpretation. In their study of the archaeal diversity at different subsurface depths they found at $1.8 \mathrm{mbsf}$ abundant sequences of Marine Group I (MGI), members of which are highly abundant in prokaryotic picoplankton of the deep ocean. However, in deeper samples from 9 and 43 mbsf (early Pleistocene and late Oligocene age, respectively) sequences of this group were absent. These observations do not support the hypothesis of long-term survival of gene sequences from archaea buried during earlier geological history of the seafloor. Still, such conclusions are based on limited sites and data and may change as more information becomes available. The DNA of various prokaryotic groups may differ in long-term preservation as a function of the chemical and physical environment, thereby changing the pattern of extant diversity over geologic time.

Although deep subseafloor sediments may harbor more than half of all prokaryotic cells on Earth (Whitman et al., 1998), it has been unknown to what extent these organisms are alive and metabolically active. The observation of this great cell number is based on direct microscopic enumeration of bacterium-like cells containing nucleic acids that stain with fluorescent stains acridine orange or 4',6-diamidino2-phenylindole (DAPI). Such stains bind nonspecifically to DNA or RNA and do not provide information on the viability of the cells. Although the cells maintain morphological and macromolecular integrity, they might still be dormant or even dead (Luna et al., 2002). The presence of ribosomes in the cells, however, appears to be coupled only to metabolically active organisms. Cell death and even starvation in pure cultures is invariably associated with loss of ribosome content (e.g., Davis et al., 1986). As an indicator of living cells in Leg 201 samples, Schippers et al. (2005) therefore used a highly sensitive molecular technique targeting specifically rRNA. Using this catalyzed reporter deposition (CARD)-FISH technique, only cells with multiple ribosome copies become visible under the fluorescence microscope. The results using general probes for either bacteria or archaea show for the first time the fraction of the total cell counts that could be identified as living prokaryotes. In multiple sediment samples taken from depths as great as 427 mbsf with stratigraphic ages of up to $16 \mathrm{Ma}$, viable bacterial cells were detected. At open-ocean Sites 1225 and 1226, about one-third of the AODC-counted cells was detected by CARD-FISH analysis and should thus be alive; at ocean-margin Sites 1227 and 1230, about one-tenth was detected. It is important to note that not all living bacteria may be detected by CARDFISH because of low ribosome content or inefficient penetration of the molecular probe into the cells. Consequently, these numbers represent minimum estimates. At all sites the abundance of archaea is apparently too low to be quantified using CARD-FISH. These observations are supported by independent quantification of $16 \mathrm{~S}$ rDNA using quantitative, real-time polymerase chain reaction (Q-PCR) which also shows a dominance of bacteria among the prokaryotic cells (Schippers and Neretin, 
in press). The lack of detectable archaeal cells is in contrast to the abundance of archaea among the 16S rRNA clone libraries obtained for the same sites (Sørensen et al., 2004; Inagaki et al., 2006; Parkes et al., 2005) or the abundance of archaeal lipids detected by biomarker analyses (Biddle et al., 2006). It is too early to conclude whether the difference reflects a bias in the molecular probe technique of CARD-FISH, a bias in the extraction and analysis methods for archaeal DNA, or a bias in the conservation of archaeal versus bacterial biomarkers.

\section{Activity Levels of Subseafloor Prokaryotes}

When total cell numbers of subseafloor communities are compared to modeled rates of biogeochemical processes, such as bacterial sulfate reduction, it is obvious that metabolic rates in the deep biosphere are orders of magnitude lower than those in surface sediments $\left(\mathrm{D}^{\prime}\right.$ Hondt et al., 2002). A general conclusion from this observation could be that most microorganisms in subseafloor sediments are either inactive or adapted to extraordinarily low metabolic activity. Schippers et al. (2005) compared CARD-FISH counts of viable cells with gross sulfate reduction rates measured by ${ }^{35} \mathrm{~S}$-radiotracer technique to calculate sulfate reduction per living bacterial cell at four sites ranging from open-ocean to ocean-margin sediments. By making some general assumptions about the energy requirement for maintenance and the potential growth yield, they calculated that turnover times of bacteria in the upper sulfate zone are in the range of 0.2 to $2 \mathrm{yr}$, both for the open-ocean and the ocean-margin sites. A similar calculation based on global estimates of carbon flux available for the subsurface bacterial community yielded turnover times of 7 to $22 \mathrm{yr}$. These values are not vastly different from turnover times of prokaryotes in soil and marine surface sediments and are considerably lower than the $\sim 1000$ yr suggested by Whitman et al. (1998) for the turnover time of the total prokaryotic population in subsurface sediments. Given this large span of calculated turnover times, we used a different approach to calculate cell-specific metabolic rate in subsurface sediments of Leg 201 sites. The results, presented in the following paragraph, also provide considerably longer turnover times.

Based on a simple transport-reaction model, D'Hondt et al. (2004) calculated for Site 1226 an areal sulfate reduction rate for the subseafloor sediment column (1.5-420 mbsf) of $1.4 \times 10^{-7} \mathrm{~mol} / \mathrm{cm}^{2} / \mathrm{yr}$. Given this rate for the sediment column, the mean sulfate reduction rate per sediment volume is $\left(\left[1.4 \times 10^{-7}\right] /\left[4.2 \times 10^{4}\right]=\right) 3.3 \times 10^{-12} \mathrm{~mol} / \mathrm{cm}^{3} / \mathrm{yr}$ or $3.3 \mathrm{pmol} / \mathrm{cm}^{3} / \mathrm{yr}$. Based on AODC counts of prokaryotic cells, the mean cell concentration in the upper $200 \mathrm{~m}$ is $5 \times 10^{6} \mathrm{cells} / \mathrm{cm}^{3}$. A fraction of these cells are sulfate-reducing microorganisms. Because sulfate reduction in this sediment section appears to be the predominant pathway of organic matter mineralization, we tentatively assume that $10 \%$ of all cells are sulfate reducers, similar to what was found in Arctic sediments by Ravenschlag et al. (2000). Thus, the total concentration of sulfate-reducing microorganisms, active or not, is on the order of $5 \times 10^{5}$ cells/ $\mathrm{cm}^{3}$. The mean cell-specific sulfate reduction rate is then $\left(\left[3.3 \times 10^{-12}\right] /\right.$ $\left.\left[5 \times 10^{5}\right]=\right) 0.0066 \times 10^{-15} \mathrm{~mol} / \mathrm{cell} / \mathrm{yr}$ or $0.007 \mathrm{fmol} / \mathrm{cell} / \mathrm{yr}$. For comparison, D'Hondt et al. (2002) calculated cell-specific sulfate reduction rates for ODP ocean-margin sites of the Japan Sea, the Peru margin, and the Nankai Trough of $0.031,0.00014$, and $3.3 \mathrm{fmol} / \mathrm{cell} / \mathrm{yr}$, respectively, using the total cell numbers for the calculation. Had they assumed that 
B.B. JøRGENSEN ET AL.

only $10 \%$ are sulfate reducers, they would have calculated 10 -fold higher cell-specific rates.

Cell-specific sulfate reduction rates in surface sediments have been calculated for a small number of coastal marine ecosystems from direct quantification of the sulfate-reducing populations using RNA- and DNA-based techniques and from direct measurements of sulfate reduction rates using ${ }^{35}$ S-labeled sulfate. In temperate coastal sediments, Sahm et al. (1999) calculated rates of 3-30 fmol/cell/yr, whereas in Arctic sediments of Svalbard, Ravenschlag et al. (2000) calculated rates of 10-50 fmol/cell/yr, 1000-fold higher than cell-specific rates calculated for Site 1226 subsurface sediments. In comparison, cell-specific rates for sulfate-reducing bacteria in laboratory cultures tend to be much higher, for example, $300-1000 \mathrm{fmol} / \mathrm{cell} / \mathrm{yr}($ mean $=500 \mathrm{fmol} / \mathrm{cell} / \mathrm{yr})$ at $0^{\circ} \mathrm{C}$ for cold-adapted sulfate reducers isolated from Arctic sediments (Knoblauch et al., 1999). This is 40,000-fold higher than the cell-specific rates at Site 1226. With a growth yield of 3-7 g dry weight of biomass per mole of organic substrate consumed, these pure cultures of sulfate reducers typically have doubling times of 3-30 days (mean $=10$ days) (Knoblauch and Jørgensen, 1999). At a given growth yield, there is an inverse relationship between cell-specific metabolism and doubling time. Thus, if we assume that sulfate-reducing microorganisms of Site 1226 have a similar growth yield as typical pure cultures, then their mean turnover time would be 40,000-fold longer (i.e., 400,000 days or $\sim 1000 \mathrm{yr}$ ). In reality, the growth yield in the deep subsurface is expectedly lower than in pure culture, given the extremely slow growth and the proportionally larger energy requirement for maintenance of cell functions. The turnover time would therefore be correspondingly longer than 1000 yr. Recently, Biddle et al. (2006) calculated turnover times for subsurface prokaryotic communities in Leg 201 Peru margin cores of $100-2000$ years.

Although these calculations yield a large span of potential turnover times, the extremely low growth rates of deep biosphere microorganisms remains enigmatic and without comparison to the much faster growing laboratory cultures. One explanation for the large difference in mean growth rates may still be that only a fraction of the bacterial population is actively growing while a large fraction may be inactive at a given time. There is accumulating evidence, both from ocean water and from sediments, that only some of the prokaryotic cells that can be quantified by direct epifluorescent counting (AODC) are metabolically active and contribute to microbially catalyzed processes (e.g., Luna et al., 2002).

It remains a challenging question in deep biosphere research how cells can maintain molecular integrity and metabolic function under the extreme low energy conditions offered by their environment, whether their turnover time is a few years or many thousand years. As a deposited sediment layer becomes buried deeper and deeper below the seafloor over millions of years, the residual organic matter in this layer becomes increasingly refractory. A mass balance calculation of the progressively slower degradation vs. the lapsed time since initial deposition indeed shows that the available energy flux from buried organic carbon is extremely low. The gradual heating during burial due to the geothermal gradient may stimulate the degradability of the organic matter, although it obviously does not increase its total pool size. Wellsbury et al. (1997) suggested that deep geothermal heating in sediments at Blake

Ridge, northwest Atlantic Ocean, could explain an observed increase in pore water acetate concentrations of 2-3 orders of magnitude relative to 
surface concentrations. A similar release of acetate was demonstrated experimentally by heating coastal surface sediments and could provide a substrate for sulfate-reducing or methanogenic microorganisms. Although this mechanism is well established for deep oil reservoirs at temperatures $>80^{\circ} \mathrm{C}$ (Cooles et al., 1987; Borgund and Barth, 1994) and was experimentally induced at much lower temperatures (Wellsbury et al., 1997), the presence of high acetate concentrations at Blake Ridge is surprising. The in situ temperatures at 700 mbsf at Blake Ridge do not exceed $30^{\circ} \mathrm{C}$, which is well within the temperature range of mesophilic prokaryotes. The high acetate concentrations therefore indicate that if the acetate is indeed utilized by microorganisms, its turnover remains extremely slow and appears to be limited by factors other than acetate availability. Otherwise, the microorganisms should be able to consume this widely used energy source of sulfate reducers and methanogens within a relatively short period.

\section{Chemical Interfaces: Case Study of Site 1229}

Chemical interfaces in the subsurface exist where diffusible species meet and are consumed in energy-yielding redox processes. Such processes may be used for energy metabolism of specialized prokaryotes and thereby provide zones of enhanced metabolic activity and increased population density. Such an enhancement is well known from chemical interfaces in more shallow sediments, for example, at the transition between sulfate and methane. A specialized microbial community of sulfate-reducing bacteria and methane-oxidizing archaea grows where sulfate and methane coexist. The two groups of prokaryotes may form unique consortia consisting of aggregates with a central colony of archaea and a peripheral coating of sulfate reducers (Boetius et al., 2000; Orphan et al., 2001). It is assumed that the archaea transfer reducing equivalents from methane to the sulfate reducers, for example in the form of $\mathrm{H}_{2}$, but the nature of this transfer is still not clear. The energy yield of the reaction available for organisms is marginal, $\sim 20 \mathrm{~kJ} /$ mol $\mathrm{CH}_{4}$, and it even has to be shared among the two partners in the consortium. In recent years, a large diversity of methane-oxidizing archaea has been identified in many different sediment environments (Knittel et al., 2005). Some of the archaea do not form consortia with sulfate reducers but appear to grow as individual cells in the sulfatemethane transition zone. It is an interesting question whether such archaea possess the entire enzymatic machinery to catalyze both the methane oxidation and the sulfate reduction within a single cell, and thereby more than double the energy yield for the individual cell.

Parkes et al. (2005) analyzed the sulfate-methane transitions at organicrich Peru margin Site 1229. This site is unusual as it has a deep brine incursion, so sulfate penetrates both downward from the overlying seawater and upward from the underlying brine. Between these two sulfate sources, methane accumulates to $\sim 2 \mathrm{mM}$ in the intermediate sulfatefree zone and meets the sulfate by diffusion into transition zones at $\sim 30$ and 90 mbsf (Shipboard Scientific Party, 2003c) (Fig. F5A). There is a striking increase in cell densities at the two sulfate-methane transitions, 10- to 1000-fold above those in the sediment above and below the transitions (Fig. F5B). At 90 mbsf, where the sediment age is $\sim 0.8$ $\mathrm{Ma}$, the highest cell densities ever encountered in subsurface sediments were detected, $1 \times 10^{10}$ cells $/ \mathrm{mL}$ sediment. This density even exceeds by 10 -fold that in the surface sediment at Site 1229. The distinct peaks in population size occur exactly at the two sulfate/methane diffusion in-
F5. Site 1229 data comparison, p. 43.

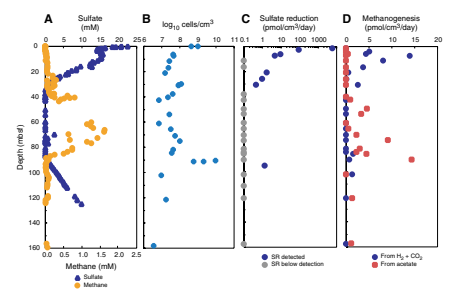


B.B. JøRGENSEN ET AL.

terfaces where there is enhanced energy supply. This zonation shows that, at least in some cases, the microbial community does indeed respond to the modern chemical environment.

Sulfate reduction was measured experimentally in samples from Site 1229 and showed an interesting distribution (Fig. F5C). Highest reduction rates were recorded near the sediment surface and in the uppermost $10 \mathrm{~m}$ of sediment. Below 10 mbsf rates were mostly below detection limit and only the data points shown in Figure F5C were significantly above detection. On that background, peaks in reduction occur near the two sulfate-methane transitions, presumably fueled by anaerobic methane oxidation. The absolute rates of sulfate reduction $\left(<10 \mathrm{pmol} \mathrm{SO}_{4}{ }^{2-} / \mathrm{cm}^{3} / \mathrm{d}\right)$ are similar to the measured rates of methanogenesis. The rates are also extremely low, 2-3 orders of magnitude lower than rates normally recorded in coastal sediments, and are near the theoretical limit of detectability for ${ }^{35} \mathrm{~S}$ radiotracer. Although the absolute rates of sulfate reduction are therefore not accurate, the distribution of activity still provides a clear picture of where the hotspots are found today in the deep subsurface. In spite of ongoing sulfate reduction, sulfate-reducing bacteria were not detected in the sequence libraries, either near the sediment surface or at the two sulfate-methane transitions (Parkes et al., 2005). The $d s r$ gene, specific for sulfate-reducing bacteria, could also not be detected among the PCR products, which seems to confirm a low representation of the known types of sulfate reducers in the community.

Analyses of $16 \mathrm{~S}$ rRNA gene diversity throughout the sediment, using denaturing gradient gel electrophoresis (DGGE) and subsequent sequencing of visible bands (Parkes et al., 2005; Fry et al., in press), show that the microbial community at 90 mbsf differs distinctly from that in the rest of the sediment column. Although methanogens were generally absent in the 16S rRNA clone libraries, the methanogen-specific gene, $m c r A$, was found at all depths analyzed, with sequence relationship to the Methanobacteriales and Methanosarcinales. Members of these groups utilize $\mathrm{H}_{2} / \mathrm{CO}_{2}$ and/or acetate for methane formation, which is consistent with the measured methane formation from both these substrates (Fig. F5D). The bacteria in the deep subsurface are thus not just survivors of earlier populations that grew at the sediment surface at a time when the energy supply was higher but have adjusted to the present chemical zonation. Site 1229 is an excellent example of such a bacterial adaptation to the chemical environment because the zonation pattern occurs twice within a sediment column covering the entire Pleistocene.

Figure F5A shows how the zones of sulfate and methane are separated, as the presence of sulfate prevents the accumulation of methane. The zones of sulfate reduction and methanogenesis are generally separated in marine sediments. Experiments have shown that sulfate reducers can outcompete methanogens for common, limiting substrates and thereby suppress methane formation. The two processes are, however, not completely mutually exclusive because methanogens can use small quantities of noncompetitive substrates and because the competition is not totally efficient. Parkes et al. (2005) used a highly sensitive radiotracer technique to measure the rate of methanogenesis in the Site 1229 sediment column. They found that methane production does in fact take place in the sulfate zone and that methane is preferentially formed from $\mathrm{CO}_{2}$ and $\mathrm{H}_{2}$ in the upper sediment layers and from acetate deeper in the core with rates up to $15 \mathrm{pmol} / \mathrm{cm}^{3} / \mathrm{d}$ (Fig. F5D). Methane does not accumulate in the sulfate zones, however, possibly because it is 
B.B. JøRGENSEN ET AL.

being removed by anaerobic methane oxidizers. It is not clear how concurrent methane formation and oxidation is energetically possible because, from a simplistic point of view, a process can be exergonic only in one direction.

Biological formation of methane within sulfate-rich sediment was also observed in sediments of the open Pacific sites (D'Hondt, Jørgensen, Miller, et al., 2003) and sites throughout the world ocean (D'Hondt et al., 2002). Concentrations of methane are very low and reflect the correspondingly low levels of organic turnover. Yet, the occurrence of methane within the sulfate zone demonstrated that methanogenesis and sulfate reduction are not mutually exclusive, even in sediments where the competition for the scarce energy resources must be fierce.

\section{SEDIMENTOLOGY AND PHYSICAL SETTING}

Highly diverse sediment types in both open-ocean and ocean-margin provinces of the eastern tropical Pacific Ocean were studied during Leg 201. The lithostratigraphy and physical properties of each of these sites are described in the Leg 201 Initial Reports volume (D'Hondt, Jørgensen, Miller, et al., 2003). Further descriptions are provided in the reports from previous DSDP and ODP cruises to the same sites: Peru Basin DSDP Leg 34 (Yeats, Hart, et al., 1976), Peru margin ODP Leg 112 (Suess, von Huene, et al., 1988), and equatorial Pacific ODP Leg 138 (Mayer, Pisias, Janecek, et al., 1992). Only a few new data obtained following Leg 201 and pertinent to the above discussions of the biogeochemistry and microbiology will be presented in the following.

At the eastern equatorial Pacific sites (1225 and 1226) total inorganic carbon (TIC) originates mostly from calcareous nannoplankton, and concentrations vary in major part between 6 and $10 \mathrm{wt} \%$. The late Miocene carbonate crisis is, however, apparent from low TIC contents in the diatom-rich zone between 200 and 300 mbsf (Meister et al., this volume b; Mayer, Pisias, Janecek, et al., 1992). The Peru margin sediments generally have TIC contents, between $<1$ and $2.5 \mathrm{wt} \%$. These low inorganic carbon concentrations are related to the predominant sedimentation of siliceous and siliciclastic material, with lowest values where upwelling, and thus diatom productivity, are strongest.

The cored sediments vary 100-fold in modern sedimentation rates (Skilbeck and Fink, this volume). The deep-sea sediments (Sites 1225, 1226,1230 , and 1231) have sedimentation rates of $1.5-2.4 \mathrm{~cm} / \mathrm{k} . y_{.}$., in accordance with earlier determinations in the eastern equatorial Pacific. Of the Peru margin sediments, Site 1227 has only a thin layer of upper Holocene sediment below which $15,700 \mathrm{yr}$ of sediment is missing. Sites 1228 and 1229 have maintained sedimentation rates of $32-98 \mathrm{~cm} / \mathrm{k} . \mathrm{y}$. over the past few thousand years. The temperatures of the cored sediments at the open-ocean sites vary from $2^{\circ} \mathrm{C}$ at the sediment surface to a maximum of $26^{\circ} \mathrm{C}$ at 400 mbsf. The shallow Peru margin sediments have temperatures of $8^{\circ}-13^{\circ} \mathrm{C}$ at the sediment surface and $16^{\circ}-20^{\circ} \mathrm{C}$ at the bottom of the drilled interval. Thus, all sediments are well within the temperature range of psychrophilic to mesophilic microorganisms.

Grain size of the sediments is a biologically important property for several reasons. It affects permeability and thus the possibility of fluid flow through the sediment. This in turn determines the diffusive or advective transport of dissolved species in the pore water and thereby affects biogeochemical zonations and substrate fluxes to the deep 
B.B. JøRGENSEN ET AL.

biosphere. It also determines the pore space available for microbial cells in the deep subsurface and thereby their ability to multiply and to actively move. Particle studies using a laser particle size analyzer show mean diameters of bulk particles in Site 1225 and 1226 sediments of 20-30 $\mu \mathrm{m}$, which is larger than the normal size range of the dominant

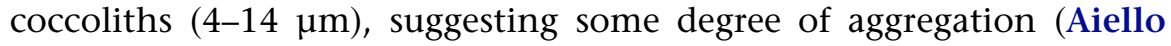
and Kellett, this volume). In the nannofossil ooze deposited during the late Miocene-Pliocene "biogenic bloom," more than 50\% of the sediment is composed of particles of $<12 \mu \mathrm{m}$ size. Unless the pore space between the coccoliths is clogged by fine particles, the pore space in unlithified oozes should certainly be sufficiently large for prokaryotic cells to move freely in the deep subseafloor sediments.

Sediment permeability was analyzed experimentally in core samples from most of the sites drilled in order to evaluate the possibility of advective flow (Gamage et al., this volume). These samples represent depths from 11 to 400 mbsf and include both open-ocean and oceanmargin subsurface environments. Permeabilities vary over two orders of magnitude, from $8 \times 10^{-19} \mathrm{~m}^{2}$ to $1 \times 10^{-16} \mathrm{~m}^{2}$, the lower representing lithified oozes and clay-rich sediments, the higher representing unlithified oozes and silt-rich sediments.

The low permeability appears to prevent vertical transport of pore fluid in Peru margin sediments to the extent that the upward flux of dissolved seawater ions from the underlying Miocene brine takes place primarily by molecular diffusion over hundreds of meters. The low permeability of the 120 - to 420 -m-thick sediments overlying the basaltic crust of the eastern tropical Pacific sites also appears to prevent vertical advective transport of pore fluid. Accordingly, none of the Leg 201 sites show chemical evidence of vertical flow. The crust itself, however, appears to be fractured and permeable to an extent that allows slow lateral flow of seawater. The existence of such fluid flow had already been indicated by earlier studies of geothermal gradients and pore water chemistry. Yet, it was a striking observation during Leg 201 that the most readily consumed oxidants, oxygen and nitrate, penetrated into the sediment also from below at Sites 1226 and 1231. It is an important conclusion from this observation that the basalt is not a source of energy-rich compounds such as hydrogen that may fuel the deep biosphere from below. Such compounds would obviously be excellent substrates for microorganisms utilizing the available oxygen or nitrate in seawater in the crust. On the other hand, the availability of electron acceptors with high free-energy yields may support bacterial utilization of products such as methane and ammonium, derived from previous microbial activity in the sediment column above. Furthermore, the flow of oxic seawater through the crust may accelerate basalt weathering and ultimately enhance chemical flux to the ocean.

\section{Minerals and Mineral Formation}

Bacterial processes in the subsurface sediment drive authigenic formation and dissolution of minerals such as pyrite, barite, dolomite, and apatite. The dynamic formation of such minerals is most clear in oceanmargin sites with highest microbial activity. Pyrite formation is distinctly due to high iron content of mainly terrestrial origin and enhanced sulfide production resulting from high organic carbon burial. Barite formation is controlled by penetration of seawater sulfate from above and upward migration of $\mathrm{Ba}^{2+}$ ions from deeply buried barite of planktonic origin. The barite horizons are therefore found just below 
B.B. JøRGENSEN ET AL.

the sulfate-methane transitions and reflect a dynamic cycle by which barite, upon further burial below the sulfate zone, dissolves, diffuses upward, and reprecipitates in the lower sulfate zone.

Intermediate minima in dissolved $\mathrm{Ca}^{2+}$ and $\mathrm{Mg}^{2+}$ within the upper 30 $\mathrm{m}$ of Peru margin sediments suggest precipitation of dolomite or other carbonate phases (Donohue et al., this volume). Dolomite was indeed found at all sites drilled on the Peru margin, from the shelf to the Peru Trench (Meister et al., this volume a). Dolomite occurs in distinct layers that probably formed relatively early after burial, based on the Sr isotopic composition of the diagenetic carbonate (Meister et al., submitted [N3]). Thus, on the Peru shelf the youngest dolomite layers often appear between 10 and $30 \mathrm{mbsf}$, where the diatomaceous sediment is still uncompacted. It is likely that formation of dolomite was not a continuous process but was coupled to geochemical interfaces, which may have migrated upward or downward as a result of varying sediment composition and organic carbon content (Meister et al., submitted [N3]). In particular, depletion of sulfate, which may inhibit dolomite formation, and the concurrent increase of alkalinity are controlling factors for dolomite precipitation (Baker and Kastner, 1981; Meister et al., this volume a). Such favorable chemical conditions are found at the sulfate-methane transitions, where microbial density and activity are particularly high (D'Hondt, Jørgensen, Miller, et al., 2003). Although formation of dolomite has been observed to take place in bacterial culture experiments and in surface sediments of a tropical lagoon (Vasconcelos et al., 1995; Warthmann et al., 2000), crystal morphologies found in ODP cores were distinctly different and did not provide direct evidence of a bacterial origin.

Biogenic magnetic minerals, magnetosomes, are formed as inclusions in the cells of magnetotactic bacteria that generally live under microoxic conditions but may also be found in anoxic zones. The magnetosomes consist primarily of magnetite but may also be greigite or pyrite and may be preserved in sediments over many millions of years. In spite of the persistence of magnetite toward iron-reducing bacteria, the magnetic minerals are chemically attacked by free sulfide in organic-rich sediments. The presence of magnetosomes is therefore indicative not only of suitable growth conditions for magnetotactic bacteria at the time of sediment deposition but also of the changing geochemical conditions that the buried sediment has undergone since then (e.g., Hesse and Stolz, 1999). In the sediments drilled during Leg 201, magnetosomes were recovered from all investigated core samples, both from open Pacific Site 1225 and Peru margin Site 1227, and even in layers with low magnetic susceptibility and significant sulfide concentrations (Ford et al., this volume). The presence of magnetosomes enabled detailed studies of magnetostratigraphy, which, together with biostratigraphy, provided an accurate age model for Site 1225 (Niitsuma et al., this volume).

\section{CONCLUSIONS}

Drilling and sampling procedures during Leg 201 were adapted to provide optimal samples for microbiology and geochemistry. Advanced piston coring was applied as deep as possible and sample recovery on deck was accomplished as quickly as possible. Subsamples for cultivation or activity experiments were taken from whole-round cores, and microbiological samples were prepared in a cold room using aseptic and 
anaerobic techniques. Intermittent warming of heat-sensitive microorganisms from the cold seabed was monitored and minimized by the new procedures. Contamination of subseafloor samples from the surface world was monitored continuously by the use of a dissolved tracer compound in the drilling fluid and fluorescent tracer particles of bacterial size deployed at the tip of the piston corer. The combined experience from Leg 201 showed that subsurface sediment samples can indeed be routinely obtained without significant contamination but that this requires special procedures and continuous contamination control.

Sediments recovered ranged from calcareous nannofossil oozes in the eastern equatorial Pacific to terrigenous sediments on the Peruvian shelf. At the open-ocean sites, the deepest cores reached basement at 122-420 mbsf with crustal ages reaching late Eocene. At the ocean-margin sites, the deepest cores reached 151-277 mbsf in sediments dating to the Pliocene or Miocene. Comprehensive pore water analyses were conducted for all sites drilled from the sediment surface down to the greatest depths reached. The pore water profiles of the main substrates and products of microbial processes provided information on the progressing mineralization of organic material and on the predominant biological energy metabolism. D'Hondt et al. (2004) used these data in a biogeochemical flux model to calculate the net reduction rates of nitrate, oxidized metals, and sulfate based on pore water concentrations of nitrate, manganese, iron, sulfate, and sulfide. In combination with solid-phase analyses, the data enabled mass balance calculations for the major microbial processes. The very complete chemical analyses made it possible to constrain the potential redox reactions that provide energy for the microbial populations. The geochemical data suggest that the subseafloor biosphere is principally fueled by organic carbon buried from the surface world and provide no evidence for a flux of electron donors coming up from the deep. In particular, fluid flow in the basaltic crust at the open Pacific sites shows that seawater could spread below the sediments without a strong change in concentration of even the most redox-active chemical species such as nitrate. Thus, at Sites 1225 and 1231, where microbial activity in the sediment column is the lowest, oxygen and nitrate remain in the crustal fluid and diffuse up into the overlying deposits. This demonstrates that energy-rich electron donors such as organic material or hydrogen are extremely scarce in the lowermost sediment column and in the basaltic basement. The lack of energy sources is confirmed by the sulfate profiles and $\delta^{34} S$ and $\delta^{18} \mathrm{O}$ values of sulfate at the two sites showing only marginal sulfate reduction throughout the 120- to 320-m-deep sediment column.

All of the microbial processes identified in the ocean-margin sediments also occur in open-ocean sediments but at a highly extended depth scale. At the ocean-margin sites and the most active open-ocean site, sulfate reduction is overall the dominant mineralization pathway. Bacterial metal reduction is also important in subsurface sediments, as $\mathrm{Fe}^{2+}$ and $\mathrm{Mn}^{2+}$ profiles show active bacterial reduction at all sites. At Peru Basin Site 1231, manganese and iron reduction are even more important than sulfate reduction for the overall mineralization in the sediment column (D'Hondt et al., 2004). Sulfate reduction varies considerably from site to site. The greatest sulfate depletion occurs within the uppermost 9 mbsf at Peru Trench Site 1230, where gas hydrate and high methane flux fuel sulfate reduction. The lowest depletion occurs at Peru Basin Site 1231, where sulfate reduction is too low to measure (Böttcher et al., this volume). Surprisingly, methane is actively 
B.B. JøRGENSEN ET AL.

produced and consumed at all sites, even in open-ocean sediments where sulfate reduction is marginal. Methane distributions show that low rates of methanogenesis occur widespread in deeply buried marine sediments. The high-resolution pore water data led to the important conclusion that different types of microbial energy metabolism, such as metal reduction, sulfate reduction, and methanogenesis, often co-occur in the sediments (D'Hondt et al., 2004). It is not well understood how these competing processes can coexist for potentially millions of years. Application of radiotracers $\left({ }^{35} \mathrm{~S}\right.$ and ${ }^{14} \mathrm{C}$ ) for detection of sulfate reduction or methanogenesis shows that this experimental approach is sufficiently sensitive to provide data on process rates in ocean-margin sediments but mostly falls below the detection limit in subsurface open-ocean sediments.

Leg 201 research explored to what extent modern microbial populations and processes in the deep subsurface are controlled by past oceanographic conditions and by resulting sediment properties. Expedition research found several examples of control exerted by the geological history of the sediments. At Site 1225, a distinct correspondence exists between depth distributions of dissolved iron and magnetic susceptibility. The current rate of iron reduction is thus controlled by the original amount and type of iron minerals deposited millions of years ago. At Site 1226 current manganese reduction is clearly a result of past ocean productivity and burial of manganese oxide. The most active manganese reduction today takes place from manganese oxides in an interval of unusually low organic carbon deposited between 8 and 16 m.y. ago. At the Peru shelf sites there are striking examples of processes focused in narrow subsurface zones associated with sedimentary intervals of high grain density, high natural gamma radiation (NGR), and high resistivity. These thin low-porosity intervals, rich in terrigenous sediment, were probably deposited during sea level lowstands. In particular, the lithologic context for zones of anaerobic methane oxidation at the sulfate/methane interface suggests that their orientation within the sediment is controlled by lithologic properties and thus by depositional history.

At all sites and throughout all sediment cores microbial cells are present at densities that generally range from $10^{8}$ cells $/ \mathrm{cm}^{3}$ at the sediment surface to $10^{5}-10^{6}$ cells $/ \mathrm{cm}^{3}$ at depth. At organic-poor open-ocean sites, the number of bacterial cells is lower than the global mean trend, whereas at high-productivity ocean-margin sites it is higher than the mean trend. An exceptional peak in population density of $10^{10}$ cells/ $\mathrm{cm}^{3}$ was discovered at a sulfate/methane interface on the Peru margin. The available global data on microbial cell numbers in subsurface marine sediments were obtained from ODP cores that were mostly drilled in ocean margin regions. There is consequently a bias in the data set, in which the large midoceanic low-productivity regions are underrepresented. A global extrapolation from mean cell densities in all cores studied until today therefore tends to overestimate the total subseafloor cell number. Future IODP cruises should include microbiological studies of low-productivity regions in order to generate a more accurate global estimate.

Extensive cultivation efforts resulted in a large number of pure cultures of subseafloor bacteria belonging to a range of known phylogenetic lineages. The new isolates have physiological properties that for some strains are in accordance with the physical-chemical environment from which they were retrieved, for others not. Most organisms are heterotrophic anaerobes, but some are aerobes although they were isolated 
B.B. JøRGENSEN ET AL.

from deep in the anoxic sediment. Most isolates are mesophilic or moderately psychrophilic in accordance with the low-temperature in situ conditions, yet there are also several thermophilic isolates from these sediments. There are no archaea among the new isolates, although both biomarker and genetic analyses indicate their presence.

Cultivation-independent DNA- and RNA-based analyses of the microbial populations provide extensive information on their phylogenetic diversity and on key genes of sulfate-reducing and methanogenic microorganisms. The $16 \mathrm{~S}$ rRNA clone libraries are dominated by uncultured lineages of bacteria and archaea for which very little can be concluded in terms of their basic physiology and metabolism. The distribution of such lineages in different biogeochemical zones, in which various potential redox couples are available for energy metabolism, would seem to indicate their functional role in the subsurface. Yet, the distribution of specific phylogenetic groups within zones dominated by sulfate reduction, manganese reduction, methanogenesis, or anaerobic methane oxidation does not provide a clear pattern based on our current understanding. It is, for example, surprising that $16 \mathrm{~S}$ rRNA genes representing known groups of sulfate-reducing bacteria of $\delta$-Proteobacteria or known lineages of methanogenic archaea are sparse in the clone libraries, even in sediment horizons where sulfate reduction or methanogenesis should dominate microbial processes according to the pore water chemistry. The links between phylogenetic diversity of microbial communities and their functional diversity in the subsurface environment are still poorly constrained. We need to determine the types of energy metabolism and carbon transformations of phylogenetically defined groups, such as the DSAG or MCG, for which there is currently little or no information about their life mode in the deep subsurface. As the database grows and new ideas and approaches are added, the pieces in this great puzzle will gradually fall into place. It should be noted, however, that this is not only a scientific problem related to deep subseafloor ecosystems but is also a limitation in studies of most other environments on the surface of our planet. This multidisciplinary research field is still in its early years but is progressing rapidly.

As one example of methodological progress following Leg 201, Schippers et al. (2005) were able to identify a living fraction of the total prokaryotic cells using of a highly sensitive RNA-based technique (CARD-FISH). Using the presence of cellular ribosomes as an indication of activity, the authors found that at least $1 / 10$ to $1 / 3$ of all cells analyzed are living bacteria. The fact that this is only a minimum estimate means that potentially all counted cells could be alive and active. One of the reasons why the question of the degree of viability is so fundamental to deep biosphere research is that the estimated mean activity and growth of the cells are extremely low. As discussed in this chapter, estimates of the potential generation time of subsurface bacteria range from less than a year to tens of thousands of years. If the mean generation times lie somewhere between tens and thousands of years, we are dealing with cellular levels of energy and carbon turnover that are many orders of magnitude below the range studied by microbiologists so far. We are therefore not able to extrapolate from current data on the maintenance metabolism or regulation of growth yield to these natural populations that may still constitute the majority of prokaryotic cells on Earth. The exploration of life at extremely low energy supply remains one of the most challenging tasks of future deep biosphere research. 
B.B. JøRGENSEN ET AL.

LEg 201 SyNTHESIS: Microbial CoMmunities

\section{ACKNOWLEDGMENTS}

This research used samples and/or data provided by the Ocean Drilling Program (ODP). ODP is sponsored by the U.S National Science Foundation (NSF) and participating countries under management of Joint Oceanographic Institutions (JOI), Inc. We thank the ODP Publication Services staff for their invaluable and competent support in completing this volume, in particular Gigi Delgado for handling all manuscripts and contacts to authors and reviewers, Lorri Peters for carefully editing the chapters, and Jennifer Rumford for the online publication. We acknowledge the important contributions of all Leg 201 shipboard and land-based scientists to the results presented in this volume. We are indebted to several Leg 201 scientists for allowing us to cite their unpublished data, in particular Heribert Cypionka, Bert Engelen, Kai-Uwe Hinrichs, Jürgen Wiegel, Udo Fehn, and Glen Snyder. Each chapter went through peer review with two external reviewers and we thank the many reviewers whose constructive comments and suggestions have greatly helped to improve the quality of this volume. Finally, we thank all Leg 201 scientists and staff members on board the JOIDES Resolution for making this a most successful and enjoyable cruise. 


\section{REFERENCES}

Aharon, P., and Fu, B., 2000. Microbial sulfate reduction rates and sulfur and oxygen isotope fractionation at oil and gas seeps in deepwater Gulf of Mexico. Geochim. Cosmochim. Acta, 64(2):233-246. doi:10.1016/S0016-7037(99)00292-6

Altabet, M.A., Francoise, R., Murray, D.W., and Prell, W.L., 1995. Climate-related variations in denitrification in the Arabian Sea from sediment ${ }^{15} \mathrm{~N} /{ }^{14} \mathrm{~N}$ ratios. Nature (London, U. K.), 373(6514):506-509. doi:10.1038/373506a0

American Public Health Association, 1989. Estimation of bacterial density. In Clesceri, L.S., Greenberg, A.E., and Trussell, R.R. (Eds.), Standard Methods for the Examination of Water and Wastewater (17th ed.): Washington D.C. (American Public Health Association), 977-980.

Baker, P.A., and Kastner, M., 1981. Constraints on the formation of sedimentary dolomite. Science, 213:215-216.

Bale, S.J., Goodman, K., Rochelle, P.A., Marchesi, J.R., Fry, J.C., Weightman, A.J., and Parkes, R.J., 1997. Desulfovibrio profundus sp. nov., a novel barophilic sulfate-reducing bacterium from deep sediment layers in the Japan Sea. Int. J. Syst. Bacteriol., 47:515-521.

Barer, M.R., and Harwood, C.R., 1999. Bacterial viability and culturability. Adv. Microb. Physiol., 41:93-137.

Barnes, S.P., Bradbrook, S.D., Cragg, B.A., Marchesi, J.R., Weightman, A.J., Fry, J.C., and Parkes, R.J., 1998. Isolation of sulfate-reducing bacteria from deep sediment layers of the Pacific Ocean. Geomicrobiol. J., 15:67-83.

Barns, S.M., Delwiche, C.F., Palmer, J.D., and Pace, N.R., 1996. Perspectives on archaeal diversity, thermophily and monophyly from environmental rRNA sequences. Proc. Natl. Acad. Sci. U. S. A., 93:9188-9193.

Biddle, J.F., Lipp, J.S., Lever, M., Lloyd, K., Sørensen, K., Anderson, R., Fredricks, H.F., Elvert, M., Kelly, T.J., Schrag, D.P., Sogin, M.L., Brenchley, J.E., Teske, A., House, C.H., and Hinrichs, K.-U., 2006. Heterotrophic archaea dominate sedimentary subsurface ecosystems off Peru. Proc. Natl. Acad. Sci. U. S. A., 103(10):3846-3851. doi:10.1073/pnas.0600035103

Biddle, K.A., Kastner, M., and Bartlett, D.H., 1999. A phylogenetic analysis of microbial communities associated with methane hydrate containing marine fluids and sediments in the Cascadia margin (ODP Site 892B). FEMS Microbiol. Lett., 177:101108.

Boetius, A., and Lochte, K., 1994. Regulation of microbial enzymatic degradation of organic matter in deep-sea sediments. Mar. Ecol.: Prog. Ser., 104:299-307.

Boetius, A., Ravenschlag, K., Schubert, C.J., Rickert, D., Widdel, F., Gieseke, A., Amann, R., Jørgensen, B.B., Witte, U., and Pfannkuche, O., 2000. A marine microbial consortium apparently mediating anaerobic oxidation of methane. Nature (London, U. K.), 407:623-626. doi:10.1038/35036572

Borgund, A.E., and Barth, T., 1994. Generation of short-chain organic-acids from crude-oil by hydrous pyrolysis. Org. Geochem., 21(8-9):943-952. doi:10.1016/ 0146-6380(94)90053-1

Böttcher, M.E., Brumsack, H.-J., and de Lange, G.J., 1998. Sulfate reduction and related stable isotope $\left({ }^{34} \mathrm{~S},{ }^{18} \mathrm{O}\right)$ variations in interstitial waters from the Eastern Mediterranean. In Robertson, A.H.F., Emeis, K.-C., Richter, C., and Camerlenghi, A. (Eds.), Proc. ODP, Sci. Results, 160, 365-373 [CD-ROM]. Available from: Ocean Drilling Program, Texas A\&M University, College Station, TX 77845-9547, U.S.A. [PDF]

Böttcher, M.E., Thamdrup, B., and Vennemann, T.W., 2001. Oxygen and sulfur isotope fractionation during anaerobic bacterial disproportionation of elemental sulfur. Geochim. Cosmochim. Acta, 65(10):1601-1609. doi:10.1016/S00167037(00)00628-1 
Bowman, J.P., and McCuaig, R.D., 2003. Biodiversity, community structural shifts, and biogeography of prokaryotes within Antarctic continental shelf sediment. Appl. Environ. Microbiol., 69(5):2463-2483. doi:10.1128/AEM.69.5.2463-2483.2003

Burdige, D.J., 2002. Sediment pore waters. In Hansell, D.A., and Carlson, C.A. (Eds.), Biogeochemistry of Marine Dissolved Organic Matter: Amsterdam (Academic Press), 611-663.

Canfield, D.E., 2001a. Biogeochemistry of sulfur isotopes. In Valley, J.W., and Cole, D.R. (Eds.), Reviews in Mineralogy and Geochemistry: Blacksburg, VA (Mineral. Soc. Am.), 607-636.

Canfield, D.E., 2001b. Isotope fractionation by natural populations of sulfate-reducing bacteria. Geochim. Cosmochim. Acta, 65(7):1117-1124. doi:10.1016/S00167037(00)00584-6

Chambers, L.A., and Trudinger, P.A., 1979. Microbiological fractionation of stable sulfur isotopes: a review and critique. Geomicrobiol. J., 1(3):249-293.

Chong, S.C., Liu, Y., Cummins, M., Valentine, D.L., and Boone, D.R., 2002. Methanogenium marinum sp. nov., a $\mathrm{H}_{2}$-using methanogen from Skan Bay, Alaska, and kinetics of $\mathrm{H}_{2}$ utilization. Antonie van Leeuwenhoek, 81(1-4):263-270. doi:10.1023/ A:1020535222281

Claypool, G.E., 2004. Ventilation of marine sediments indicated by depth profiles of porewater sulfate and $\delta^{34}$ S. In Hill, R.J., Leventhal, J., Aizenshtat, Z., Beadecker, M.J., Claypool, G.E., Eganhouse, R., Goldhaber, M.B., and Peters, K. (Eds.), Geochemical Investigations in Earth and Space Science. Spec. Publ.-Geochem. Soc., 9:59-65.

Claypool, G.E., and Kaplan, I.R., 1974. The origin and distribution of methane in marine sediments. In Kaplan, I.R. (Ed.), Natural Gases in Marine Sediments: New York (Plenum), 99-139.

Cooles, G.P., Mackenzie, A.S., and Parkes, R.J., 1987. Non-hydrocarbons of significance in petroleum exploration: volatile fatty acids and non-hydrocarbon gases. Mineralog. Mag., 51:483-493.

Cragg, B.A., Parkes, R.J., Fry, J.C., Herbert, R.A., Wimpenny, J.W.T., and Getliff, J.M., 1990. Bacterial biomass and activity profiles within deep sediment layers. In Suess, E., von Huene, R., et al., Proc. ODP, Sci. Results, 112: College Station, TX (Ocean Drilling Program), 607-619.

Cragg, B.A., Parkes, R.J., Fry, J.C., Weightman, A.J., Rochelle, P.A., and Maxwell, J.R., 1996. Bacterial populations and processes in sediments containing gas hydrates (ODP Leg 146: Cascadia margin). Earth Planet. Sci. Lett., 139(3-4):497-507. doi:10.1016/0012-821X(95)00246-9

Davis, B.D., Luger, S.M., and Tai, P.C., 1986. Role of ribosome degradation in the death of starved Escherichia coli cells. J. Bacteriol. 166:439-445.

D'Hondt, S.D., Rutherford, S., and Spivack., A.J., 2002. Metabolic activity of subsurface life in deep-sea sediments. Science, 295(5562):2067-2070. doi:10.1126/science.1064878

D'Hondt, S.L., Jørgensen, B.B., Miller, D.J., Batzke, A., Blake, R., Cragg, B.A., Cypionka, H., Dickens, G.R., Ferdelman, T., Hinrichs, K.-H., Holm, N.G., Mitterer, R., Spivack, A., Wang, G., Bekins, B., Engelen, B., Ford, K., Gettemy, G., Rutherford, S.D., Sass, H., Skilbeck, C.G., Aiello, I.W., Guerin, G., House, C., Inagaki, F., Meister, P., Naehr, T., Niitsuma, S., Parkes, R.J., Schippers, A., Smith, D.C., Teske, A., Wiegel, J., Naranjo Padillo, C., and Solis Acosta, J.L., 2004. Distributions of microbial activities in deep subseafloor sediments. Science, 306(5705):2216-2221. doi:10.1126/ science.1101155

D'Hondt, S.L., Jørgensen, B.B., Miller, D.J., et al., 2003. Proc. ODP, Init. Repts., 201 [CD-ROM]. Available from: Ocean Drilling Program, Texas A\&M University, College Station TX 77845-9547, USA. [HTML]

Dickens, G.R., Schroeder, D., Hinrichs, K.-U., and the Leg 201 Scientific Party, 2003. The pressure core sampler (PCS) on Ocean Drilling Program Leg 201: general operations and gas release. In D'Hondt, S.L., Jørgensen, B.B., Miller, D.J., et al., Proc. 
ODP, Init. Repts., 201, 1-22 [CD-ROM]. Available from: Ocean Drilling Program, Texas A\&M University, College Station TX 77845-9547, USA. [HTML]

Franzmann, P.D., Liu, Y., Balkwill, D.L., Aldrich, H.C., Conway de Macario, E., and Boone, D.R., 1997. Methanogenium frigidum sp. nov., a psychrophilic, $\mathrm{H}_{2}$-using methanogen from Ace Lake, Antarctica. Int. J. Syst. Bacteriol., 47:1068-1072.

Fritz, P., Basharmal, G.M., Drimmie, R.J., Ibsen, J., and Qureshi, R.M., 1989. Oxygen isotope exchange between sulphate and water during bacterial reduction of sulphate. Chem. Geol., 79:99-105.

Fry, J.C., Webster, G., Cragg, B.A., Weightman, A.J., and Parkes, R.J., 2006. Analysis of DGGE profiles to explore the relationship between prokaryotic community composition and biogeochemical processes in deep subseafloor sediments from the Peru margin. FEMS Microbiol. Ecol. doi:10.1111/j.1574-6941.2006.00144.x

Ganeshram, R.S., Pedersen, T.F., Calvert, S.E., and Murray, J.W., 1995. Large changes in oceanic nutrient inventories from glacial to interglacial periods. Nature (London, U. K.), 376(6543):755-758. doi:10.1038/376755a0

Hesse, P.P., and Stolz, J.F., 1999. Bacterial magnetite and the Quaternary climate record. In Maher, B.A., and Thompson, R. (Eds.), Quaternary Climates, Environments, and Magnetism: Cambridge (Cambridge Univ. Press), 163-198.

House, C.H., Cragg, B.A., Teske, A., and the Leg 201 Scientific Party, 2003. Drilling contamination tests during ODP Leg 201 using chemical and particulate tracers. In D'Hondt, S.L., Jørgensen, B.B., Miller, D.J., et al., Proc. ODP, Init. Repts., 201, 1-19 [CD-ROM]. Available from: Ocean Drilling Program, Texas A\&M University, College Station TX 77845-9547, USA. [HTML]

Hugenholtz, P., Pitulle, C., Hershberger, K.L., and Pace, N.R., 1998. Novel division level bacterial diversity in a Yellowstone hot spring. J. Bacteriol., 180:366-376.

Inagaki, F., Nunoura, T., Nakagawa, S., Teske, A., Lever, M., Lauer, A., Suzuki, M., Takai, K., Delwiche, M., Colwell, F.S., Nealson, K.H., Horikoshi, K., D'Hondt, S.L., and Jørgensen, B.B., 2006. In search of the deep biosphere: biogeographical distribution and diversity of microbes in methane hydrate-bearing deep marine sediments on the Pacific Ocean margin. Proc. Natl. Acad. Sci. U. S. A., 103:2815-2820. doi:10.1073/pnas.0511033103

Inagaki, F., Okada, H., Tsapin, A.I., and Nealson, K.H., 2005. Microbial survival: the paleome: a sedimentary genetic record of past microbial communities. Astrobiology, 5(2):141-153. doi:10.1089/ast.2005.5.141

Inagaki, F., Suzuki, M., Takai, K., Oida, H., Sakamoto, T., Aoki, K., Nealson, K.H., and Horikoshi, K., 2003. Microbial communities associated with geological horizons in coastal subseafloor sediments from the Sea of Okhotsk. Appl. Environ. Microbiol., 69(12):7224-7235. doi:10.1128/AEM.69.12.7224-7235.2003

Inagaki, F., Takai, K., Komatsu, T., Kanamatsu, T., Fujioka, K., and Horikoshi, K., 2001. Archaeology of Archaea: geomicrobiological record of Pleistocene thermal events concealed in a deep-sea subseafloor environment. Extremophiles, 5(6):385-392. doi:10.1007/s007920100211

Kaeberlein, T., Lewis, K., and Epstein, S.S., 2002. Isolating "uncultivable" microorganisms in pure culture in a simulated natural environment. Science, 296(5570):11271129. doi:10.1126/science.1070633

Kallmeyer, J., Ferdelman, T.G., Weber, A., Fossing, H., and Jørgensen, B.B., 2004. A cold chromium distillation procedure for radiolabeled sulfide applied to sulfate reduction measurements. Limnol. Oceanogr.: Methods, 2:171-180.

Kaplan, I.R., and Rittenberg, S.C., 1964. Microbiological fractionation of sulfur isotopes. J. Gen. Microbiol., 34:195-212.

Kastner, M., Elderfield, H., Martin, J.B., Suess, E., Kvenvolden, K.A., and Garrison, R.E., 1990. Diagenesis and interstitial-water chemistry at the Peruvian continental margin-major constituents and strontium isotopes. In Suess, E., von Huene, R., et al., Proc. ODP, Sci. Results, 112: College Station, TX (Ocean Drilling Program), 413440. 
Klein, M., Friedrich, M., Roger, A.J., Hugenholtz, P., Fishbain, S., Abicht, H., Blackall, L.L., Stahl, D.A., and Wagner, M., 2001. Multiple lateral transfers of dissimilatory sulfite reductase genes between major lineages of sulfate-reducing prokaryotes. $J$. Bacteriol., 183(20):6028-6035. doi:10.1128/JB.183.20.6028-6035.2001

Knittel, K., Lösekann, T., Boetius, A., Kort, R., and Amann, R., 2005. Diversity and distribution of methanotrophic archaea at cold seeps. Appl. Environ. Microbiol., 71(1):467-479. doi:10.1128/AEM.71.1.467-479.2005

Knoblauch, C., and Jørgensen, B.B., 1999. Effect of temperature on sulfate reduction, growth rate, and growth yield in five psychrophilic sulfate-reducing bacteria from Arctic sediments. Environ. Microbiol., 1(5):457-467. doi:10.1046/j.14622920.1999.00061.x

Knoblauch, C., Jørgensen, B.B., and Harder, J., 1999. Community size and metabolic rates of psychrophilic sulfate-reducing bacteria in Arctic marine sediments. Appl. Environ. Microbiol., 65:4230-4233.

Kvenvolden, K.A., 1993. Gas hydrates-geological perspective and global change. Rev. Geophys., 31(2):173-188. doi:10.1029/93RG00268

Lee, Y.-J., Wagner, I.D., Brice, M.E., Kevbrin, V.V., Mills, G.L., Romanek, C.S., and Wiegel, J., 2005. Thermosedimentibacter oceani gen. nov., sp. nov. and Thermosediminibacter litoriperuensis sp. nov., new anaerobic thermophilic bacteria isolated from Peru margin. Extremophiles, 9:375-373.

Lomstein, B.A., Jørgensen, B.B., Schubert, C.J., and Niggemann, J., 2006. Amino acid biogeo- and stereochemistry in coastal Chilean sediments. Geochim. Cosmochim. Acta., 70(12):2970-2989. doi:10.1016/j.gca.2006.03.015

Luna, G.M., Dell'Anno, A., Giuliano, L., and Danovaro, R., 2004. Bacterial diversity in deep Mediterranean sediments: relationship with the active bacterial fraction and substrate availability. Environ. Microbiol., 6(7):745-753. doi:10.1111/j.14622920.2004.00611.x

Luna, G.M., Manini, E., and Danovaro, R., 2002. Large fraction of dead and inactive bacteria in coastal marine sediments: comparison of protocols for determination and ecological significance. Appl. Environ. Microbiol., 68(7):3509-3513. doi:10.1128/AEM.68.7.3509-3513.2002

Marchesi, J.R., Weightman, A.J., Cragg, B.A., Parkes, R.J., and Fry, J.C., 2001. Methanogen and bacterial diversity and distribution in deep gas hydrate sediments from the Cascadia margin as revealed by $16 \mathrm{~S}$ rRNA molecular analysis. FEMS Microbiol. Ecol., 34(3):221-228. doi:10.1111/j.1574-6941.2001.tb00773.x

Martin, J.B., Gieskes, J.M., Torres, M., and Kastner, M., 1993. Bromide and iodine in Peru margin sediments and pore fluids: implication for fluid origins. Geochim. Cosmochim. Acta, 57(18):4377-4389. doi:10.1016/0016-7037(93)90489-J

Mayer, L., Pisias, N., Janecek, T., et al., 1992. Proc. ODP, Init. Repts., 138 (Pts. 1 and 2): College Station, TX (Ocean Drilling Program).

Mikucki, J.A., Liu, Y., Delwiche, M., Colwell, F.S., and Boone, D.R., 2003. Isolation of a methanogen from deep marine sediments that contain methane hydrates, and description of Methanoculleus submarinus sp. nov. Appl. Environ. Microbiol., 69(6):3311-3316. doi:10.1128/AEM.69.6.3311-3316.2003

Mitzutani, Y., and Rafter, T.A., 1973. Isotopic behavior of sulphate oxygen in the bacterial reduction of sulphate. Geochem. J., 6:183-191.

Mitterer, R.M., 1993. The diagenesis of proteins and amino acids in fossil shells. In Engel, M.H., and Macko, S.A. (Eds.), Organic Geochemistry: Principles and Applications: New York (Plenum), 739-753.

Newberry, C.J., Webster, G., Cragg, B.A., Parkes, R.J., Weightman, A.J., and Fry, J.C., 2004. Diversity of prokaryotes and methanogenesis in deep subsurface sediments from the Nankai Trough, Ocean Drilling Program Leg 190. Environ. Microbiol., 6(3):274-287. doi:10.1111/j.1462-2920.2004.00568.x

Nogi, Y., Masui, N., and Kato, C., 1998. Photobacterium profundum sp. nov., a new, moderately barophilic bacterial species isolated from deep-sea sediment. Extremophiles, 2(1):1-8. doi:10.1007/s007920050036 
Oremland, R.S., Culbertson, C., and Simoneit, B.R.T., 1982. Methanogenic activity in sediment from Leg 64, Gulf of California. In Curray, J.R., Moore, D.G., et al., Init. Repts. DSDP, 64 (Pt. 2): Washington (U.S. Govt. Printing Office), 759-762.

Orphan, V.J., House, C.H., Hinrichs, K.-U., McKeegan, K.D., and DeLong, E.F., 2001. Methane-consuming archaea revealed by directly coupled isotopic and phylogenetic analysis. Science, 293(5529):484-487. doi:10.1126/science.1061338

Parkes, R.J., Cragg, B.A., Bale, S.J., Getliff, J.M., Goodman, K., Rochelle, P.A., Fry, J.C., Weightman, A.J., and Harvey, S.M., 1994. Deep bacterial biosphere in Pacific Ocean sediments. Nature (London, U. K.), 371(6496):410-413. doi:10.1038/ 371410a0

Parkes, R.J., Cragg, B.A., and Wellsbury, P., 2000. Recent studies on bacterial populations and processes in subseafloor sediments: a review. Hydrogeol. Rev., 8(1):11-28. doi:10.1007/PL00010971

Parkes, R.J., Webster, G., Cragg, B.A., Weightman, A.J., Newberry, C.J., Ferdelman, T.G., Kallmeyer, J., Jørgensen, B.B., Aiello, I.W., and Fry, J.C., 2005. Deep sub-seafloor prokaryotes stimulated at interfaces over geological time. Nature (London, $U$. K.), 436(7049):390-394. doi:10.1038/nature03796

Paytan, A., Kastner, M., Campbell, D., and Thiemens, M.H., 1998. Sulfur isotopic composition of Cenozoic seawater sulfate. Science, 282(5393):1459-1462. doi:10.1126/science.282.5393.1459

Pedersen, K., Hallbeck, L., Arlinger, J., Erlandson, A.-C., and Jahromi, N., 1997. Investigation of the potential for microbial contamination of deep granitic aquifers during drilling using 16S rRNA gene sequencing and culturing methods. J. Microbiol. Methods, 30(3):179-192. doi:10.1016/S0167-7012(97)00066-3

Ravenschlag, K., Sahm, K., Knoblauch, C., Jørgensen, B.B., and Amann, R., 2000. Community structure, cellular rRNA content, and activity of sulfate-reducing bacteria in marine Arctic sediments. Appl. Environ. Microbiol., 66(8):3592-3602. doi:10.1128/AEM.66.8.3592-3602.2000

Rochelle, P.A., Cragg, B.A., Fry, J.C., Parkes, R.J., and Weightman, A.J., 1994. Effect of sample handling on estimation of bacterial diversity in marine sediments by $16 \mathrm{~S}$ rRNA gene sequence analysis. FEMS Microbiol. Ecol., 15(1-2):25-226. doi:10.1111/ j.1574-6941.1994.tb00245.x

Rudnicki, M.D., Elderfield, H., and Spiro, B., 2001. Fractionation of sulfur isotopes during bacterial sulfate reduction in deep ocean sediments at elevated temperatures. Geochim. Cosmochim. Acta, 65(5):777-789. doi:10.1016/S00167037(00)00579-2

Sahm, K., MacGregor, B.J., Jørgensen, B.B., and Stahl, D.A., 1999. Sulfate reduction and vertical distribution of sulfate-reducing bacteria quantified by rRNA slot-blot hybridization in a coastal marine sediment. Environ. Microbiol., 1(1):65-74. doi:10.1046/j.1462-2920.1999.00007.x

Schippers, A., and Neretin, L.N., 2006. Quantification of microbial communities in near-surface and deeply buried marine sediments on the Peru continental margin using real-time PCR. Environ. Microbiol., 8(7):1251-1260. doi:10.1111/j.14622920.2006.01019.x

Schippers, A., Neretin, L.N., Kallmeyer, J., Ferdelman, T.G., Cragg, B.A., Parkes R.J., and Jørgensen, B.B., 2005. Prokaryotic cells of the deep sub-seafloor biosphere identified as living bacteria. Nature (London, $U$. K.), 433(7028):861-864. doi:10.1038/nature03302

Schleifer, K.H., and Kandler, O., 1972. Peptidoglycan types of bacterial cell walls and their taxonomic implications. Bacteriol. Rev., 36:407-477.

Sharp, J.H., Carlson, C.A., Peltzer, E.T., Castle-Ward, D.M., Savidge, K.B., and Rinker, K.R., 2002. Final dissolved organic carbon broad community intercalibration and preliminary use of DOC reference materials. Mar. Chem., 77(4):239-253. doi:10.1016/S0304-4203(02)00002-6

Shipboard Scientific Party, 2003a. Explanatory Notes. In D'Hondt, S.L., Jørgensen, B.B., Miller, D.J., et al., Proc. ODP, Init. Repts., 201, 1-103 [CD-ROM]. Available 
from: Ocean Drilling Program, Texas A\&M University, College Station TX 778459547, USA. [HTML]

Shipboard Scientific Party, 2003b. Site 1225. In D'Hondt, S.L., Jørgensen, B.B., Miller, D.J., et al., Proc. ODP, Init. Repts., 201, 1-86 [CD-ROM]. Available from: Ocean Drilling Program, Texas A\&M University, College Station TX 77845-9547, USA. [HTML]

Shipboard Scientific Party, 2003c. Site 1229. In D'Hondt, S.L., Jørgensen, B.B., Miller, D.J., et al., Proc. ODP, Init. Repts., 201, 1-78 [CD-ROM]. Available from: Ocean Drilling Program, Texas A\&M University, College Station TX 77845-9547, USA. [HTML]

Shipboard Scientific Party, 2003d. Site 1230. In D'Hondt, S.L., Jørgensen, B.B., Miller, D.J., et al., Proc. ODP, Init. Repts., 201, 1-107 [CD-ROM]. Available from: Ocean Drilling Program, Texas A\&M University, College Station TX 77845-9547, USA. [HTML]

Smith, D.C., Spivack, A.J., Fisk, M.R., Haveman, S.A., and Staudigel, H., 2000. Tracerbased estimates of drilling-induced microbial contamination of deep sea crust. Geomicrobiol. J., 17:207-219. doi:10.1080/01490450050121170

Smith, D.C., Spivack, A.J., Fisk, M.R., Haveman, S.A., Staudigel, H., and ODP Leg 185 Shipboard Scientific Party, 2000. Methods for quantifying potential microbial contamination during deep ocean coring. ODP Tech. Note, 28 [Online]. Available from World Wide Web: http://www-odp.tamu.edu/publications/tnotes/tn28/ INDEX.HTM. [Cited 2002-03-30]

Sorensen, K.B., Lauer, A., and Teske, A., 2004. Archaeal phylotypes in a metal-rich, low-activity deep subsurface sediment of the Peru Basin, ODP Leg 201, Site 1231. Geobiology, 2(3):151-161. doi:10.1111/j.1472-4677.2004.00028.x

Springer, E., Sachs, M.S., Woese, C.R., and Boone, D.R., 1995. Partial gene sequences for the alpha-subunit of methyl-coenzyme M reductase (MCR1) as a phylogenetic tool for the family Methanosarcinaceae. Int. J. Syst. Bacteriol., 45:554-559.

Stahl, D.A., Fishbain, S., Klein, M., Baker, B.J., and Wagner, M., 2002. Origins and diversification of sulfate-respiring microorganisms. Antonie van Leeuwenhoek, 81:189-195.

Suess, E., von Huene, R., et al., 1988. Proc. ODP, Sci. Results, 112: College Station, TX (Ocean Drilling Program).

Takai, K., and Horikoshi, K., 1999. Genetic diversity of archaea in deep-sea hydrothermal vent environments. Genetics, 152:1285-1297.

Tarafa, M.E., Whelan, J.K., Oremland, R.S., and Smith, R.L., 1987. Evidence of microbiological activity in Leg 95 (New Jersey Transect) sediments. In Poag, C.W., Watts, A.B., et al., Init. Repts. DSDP, 95: Washington (U.S. Govt. Printing Office), 635-640.

Vasconcelos, C., McKenzie, J.A., Berrnasconi, S., Grujic, D., and Tiens, A.J., 1995. Microbial mediation as a possible mechanism for natural dolomite formation at low temperatures, Nature (London, U. K.), 377(6546):220-222. doi:10.1038/ 377220a0

Ventriani, C., Jannasch, H.W., MacGregor, B.J., Stahl, D.A., and Reysenbach, A.L., 1999. Population structure and phylogenetic characterization of marine benthic Archaea in deep-sea sediments. Appl. Environ. Microbiol., 65:4375-4384.

Warthmann, R., van Lith, Y., Vasconcelos, C., McKenzie, J.A., and Karpoff, A.M., 2000. Bacterially induced dolomite precipitation in anoxic culture experiments. Geology, 28(12):1091-1094. doi:10.1130/0091-7613(2000)028<1091:BIDPIA > 2.3.CO;2

Webster, G., Parkes, R.J., Cragg, B.A., Newberry, C.J., Weightman, A.J., and Fry, J.C., in press. Prokaryotic community composition and biogeochemical processes in deep subseafloor sediments from the Peru margin. FEMS Microbiol. Ecol. doi:10.1111/ j.1574-6941.2006.00147.x

Webster, G., Parkes, R.J., Fry, J.C., and Weightman, A.J., 2004. Widespread occurrence of a novel division of bacteria identified by $16 \mathrm{~S}$ rRNA gene sequences originally found in deep marine sediments. Appl. Environ. Microbiol., 70(9):5708-5713. doi:10.1128/AEM.70.9.5708-5713.2004

Wefer, G., Heinze, P., and Suess, E., 1990. Stratigraphy and sedimentation rates from oxygen isotope composition, organic carbon content, and grain-size distribution 
B.B. JøRGENSEN ET AL.

at the Peru upwelling region: Holes 680B and 686B. In Suess, E., von Huene, R., et al., Proc. ODP, Sci. Results, 112: College Station, TX (Ocean Drilling Program), 355367.

Wellsbury, P., Goodman, K., Barth, T., Cragg, B.A., Barnes, S.P., and Parkes, R.J., 1997. Deep marine biosphere fueled by increasing organic matter availability during burial and heating. Nature (London, U. K.), 388(6642):573-576. doi:10.1038/41544

Wellsbury, P., Goodman, K., Cragg, B.A., and Parkes, R.J., 2000. The geomicrobiology of deep marine sediments from Blake Ridge containing methane hydrate (Sites 994, 995, and 997). In Paull, C.K., Matsumoto, R., Wallace, P.J., and Dillon, W.P. (Eds.), Proc. ODP, Sci. Results, 164: College Station, TX (Ocean Drilling Program), 379-391. [HTML]

Whelan, J.K., Oremland, R., Tarafa, M., Smith, R., Howarth, R., and Lee, C., 1986. Evidence for sulfate-reducing and methane producing microorganisms in sediments from Sites 618, 619, and 622. In Bouma, A.H., Coleman, J.M., Meyer, A.W., et al., Init. Repts. DSDP, 96: Washington (U.S. Govt. Printing Office), 767-775.

Whitman, W.B., Coleman, D.C., and Wiebe, W.J., 1998. Prokaryotes: the unseen majority. Proc. Natl. Acad. Sci. U. S. A., 95(12):6578-6583. doi:10.1073/ pnas.95.12.6578

Woese, C.R., Kandler, O., and Wheelis, M., 1990. Towards a natural system of organisms: proposal for the domains Archaea, bacteria, and Eucarya. Proc. Natl. Acad. Sci. U. S. A., 87:4576-4579.

Wortmann, U.G., Bernasconi, S.M., and Böttcher, M.E., 2001. Hypersulfidic deep biosphere indicates extreme sulfur isotope fractionation during single-step microbial sulfate reduction. Geology, 29(7):647-650. doi:10.1130/0091-7613(2001)029<0647: HDBIES $>2.0 . \mathrm{CO} ; 2$

Yeats, R.S., Hart, S.R., et al., 1976. Init. Repts DSDP, 34: Washington (U.S. Govt. Printing Office).

Zak, I., Sakai, H., and Kaplan, I.R., 1980. Factors controlling the ${ }^{18} \mathrm{O} /{ }^{16} \mathrm{O}$ and ${ }^{34} \mathrm{~S} /{ }^{32} \mathrm{~S}$ isotope ratios of ocean sulfates, evaporites and interstitial sulfates from modern deep sea sediments. In Goldberg, E.D., Horibe, Y., and Saruhashi, K. (Eds.), Isotope Marine Chemistry: Tokyo (Rokakuho), 339-373.

Zengler, K., Toledo, G., Rappé, M., Elkins, J., Mathur, E.J., Short, J.M., and Keller, M., 2002. Cultivating the uncultured. Proc. Natl. Acad. Sci. U. S. A., 99(24):1568115686. doi:10.1073/pnas.252630999 
B.B. JøRGENSEN ET AL.

Leg 201 SyNTheSIS: Microbial Communities

Figure F1. Locations of drill sites in the eastern tropical Pacific Ocean and the Peru margin occupied during Leg 201. A. Overview showing drill sites, each of which was also occupied during (B) Leg 138 or (C) Leg 112. (Continued on next page.)

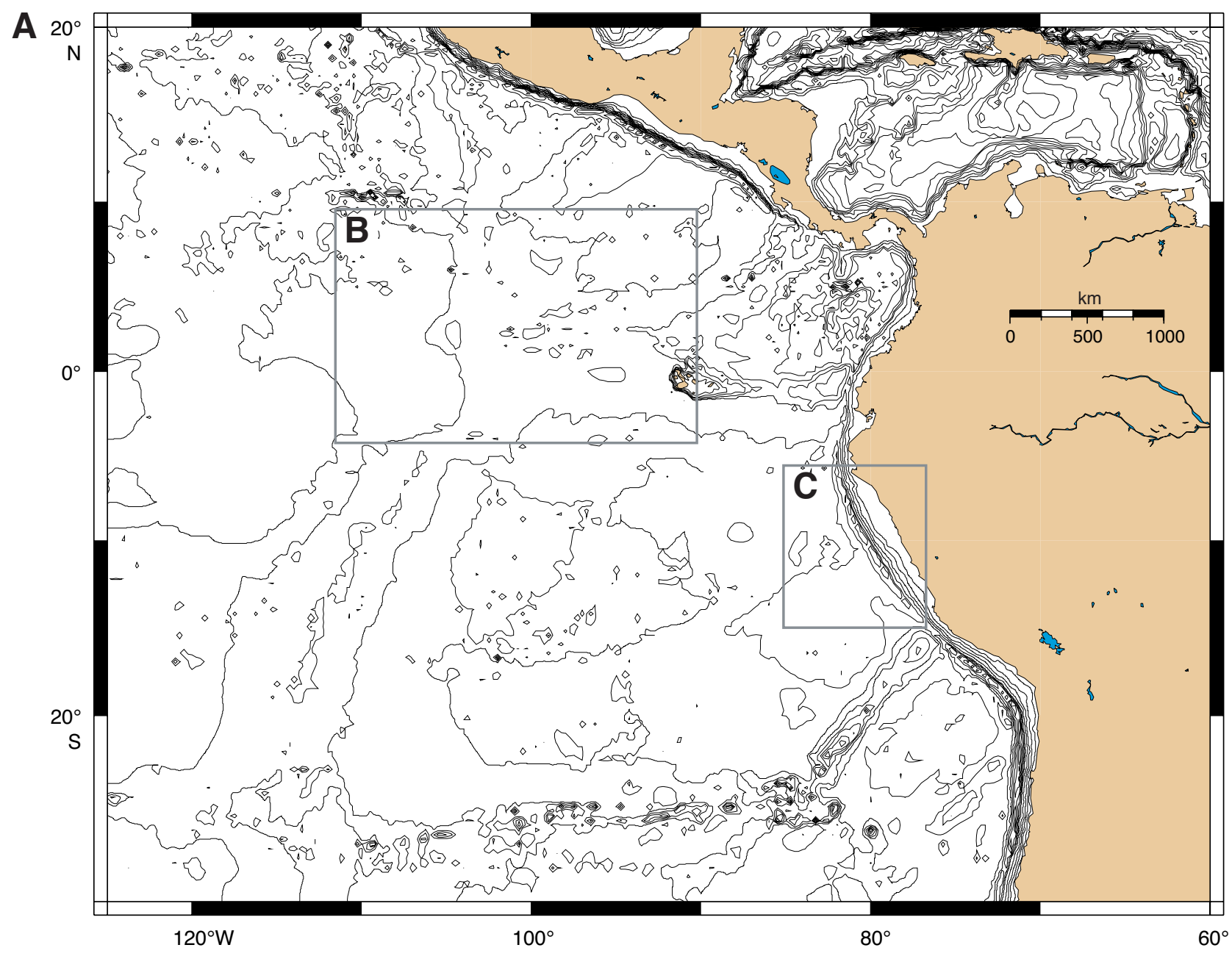




\section{B.B. JøRGENSEN ET AL.}

Figure F1. (continued). B. Detail map of equatorial Pacific sites with Leg 201 numbers. Previous ODP designations are in parentheses. C. Detail map of Peru margin sites. Previous DSDP/ODP site designations are in parentheses (from D’Hondt, Jørgensen, Miller et al., 2003).

B
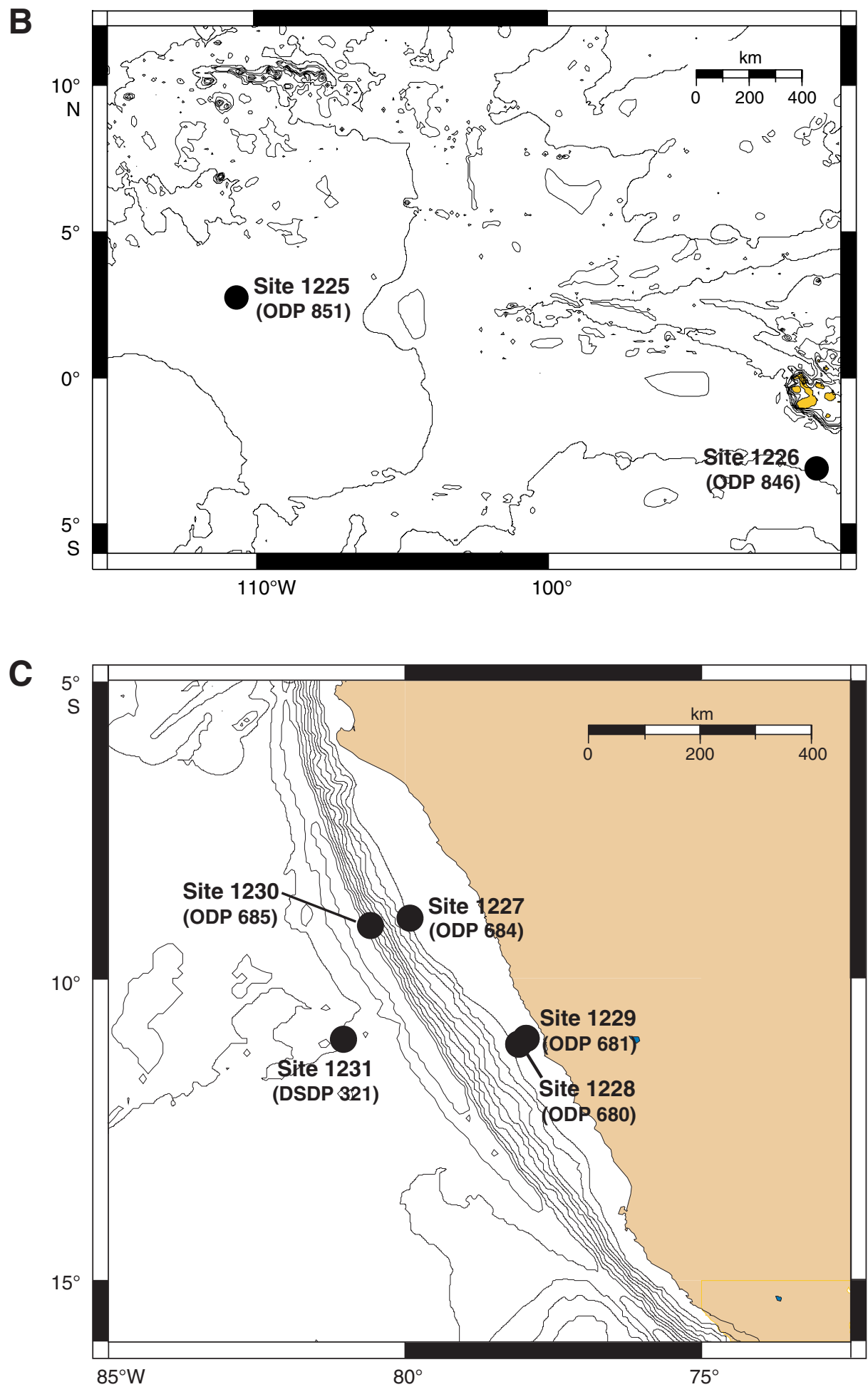


\section{B.B. JøRGENSEN ET AL.}

Figure F2. Site 1226 in the eastern equatorial Pacific. A. Gross rates of sulfate reduction (SR) measured by ${ }^{35} \mathrm{~S}_{-} \mathrm{SO}_{4}{ }^{2-}$ radiotracer experiments. Shaded circles $=$ rate data below the detection limit of this method, blue circles $=$ rates significantly above this limit. B. Sulfate and methane concentrations in pore water. C. Dissolved $\mathrm{Mn}$ and $\mathrm{H}_{2} \mathrm{~S}$ concentrations in pore water (data from D'Hondt, Jørgensen, Miller et al., 2003; Parkes et al., 2005).
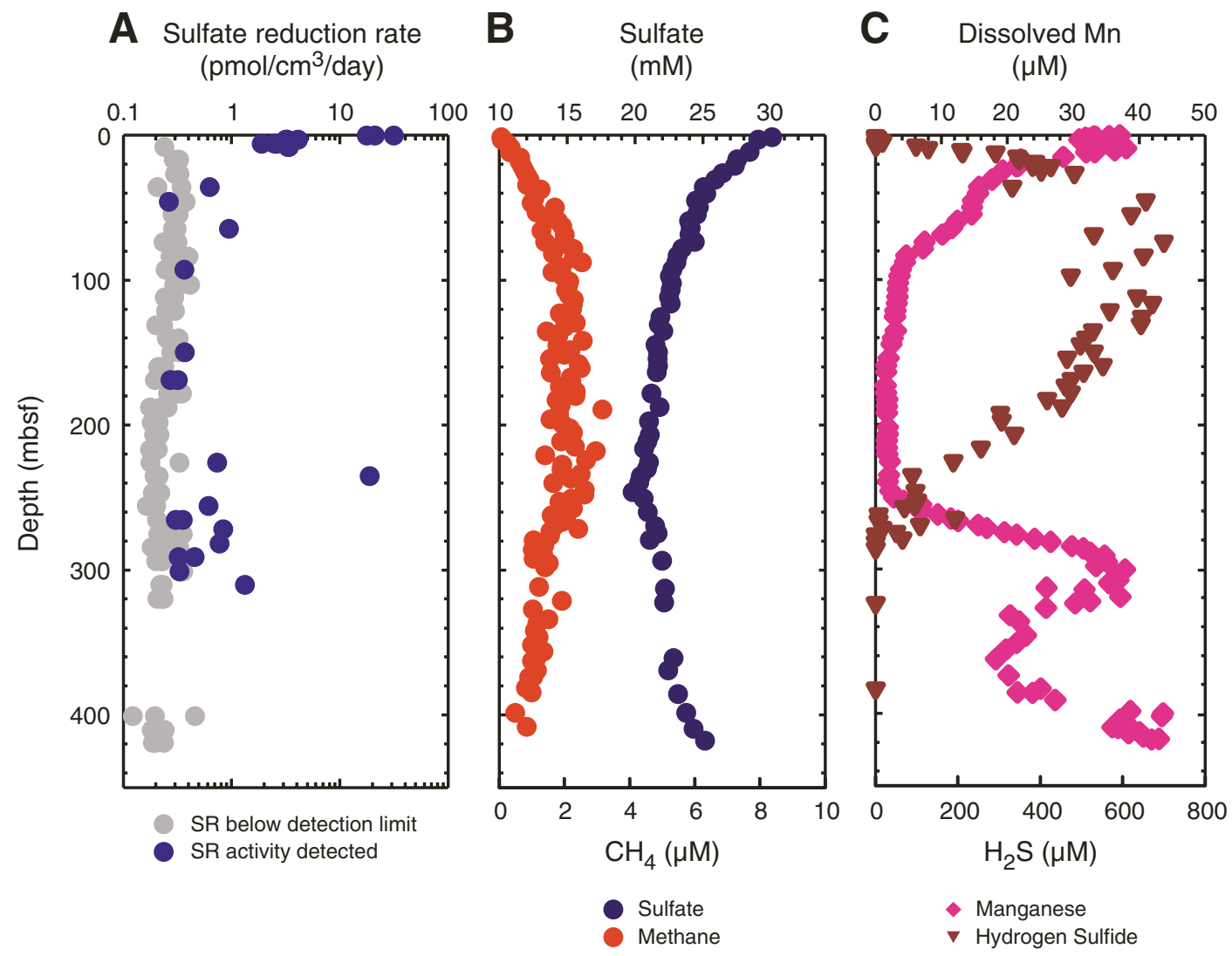


\section{B.B. JøRGENSEN ET AL.}

Figure F3. Site 1226 in the eastern equatorial Pacific. Vertical profiles of pore water chemistry and of sulfur and oxygen isotope variations in pore water sulfate (data from Böttcher et al., this volume, and Blake et al., this volume). DIC = dissolved inorganic carbon.

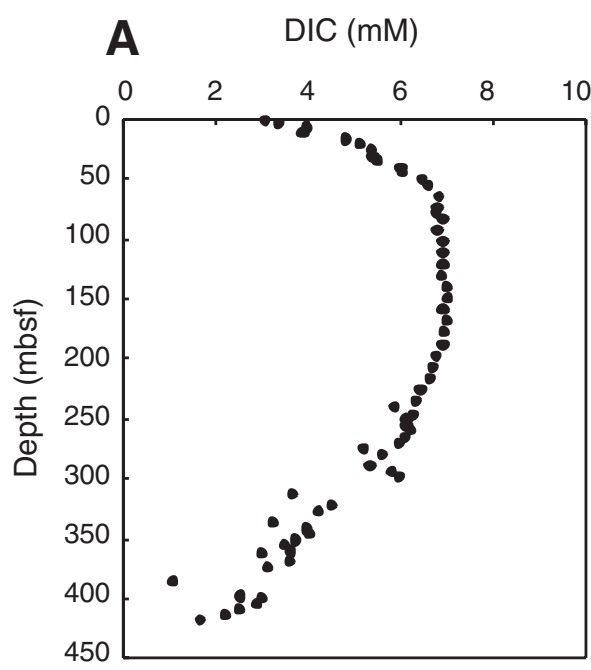

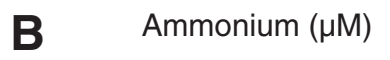

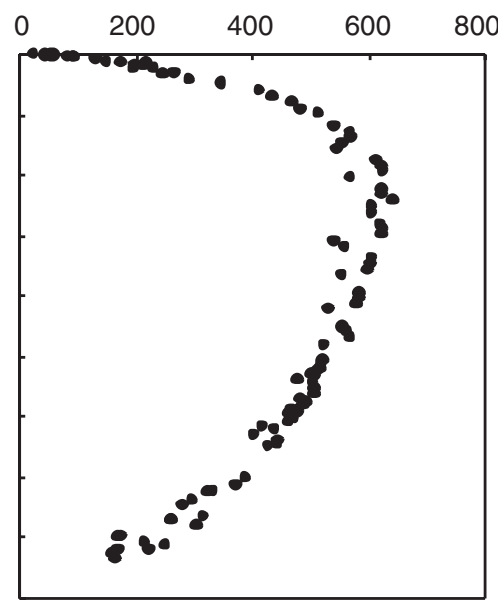

E $\delta^{34} \mathrm{~S}^{-\mathrm{SO}_{4}}{ }^{2-}(\% \circ)$

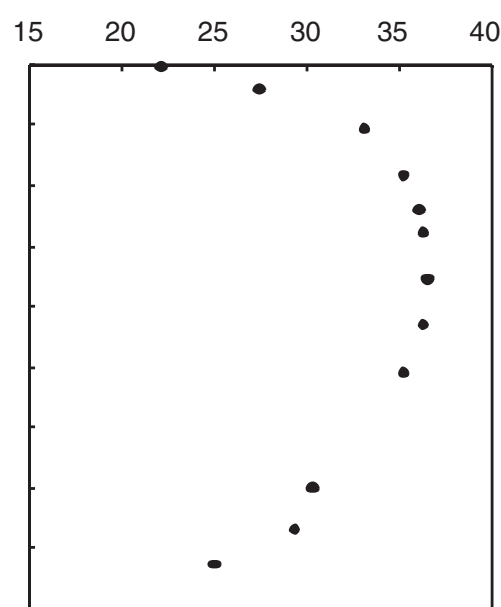

C $\mathrm{H}_{2} \mathrm{~S}(\mathrm{mM})$

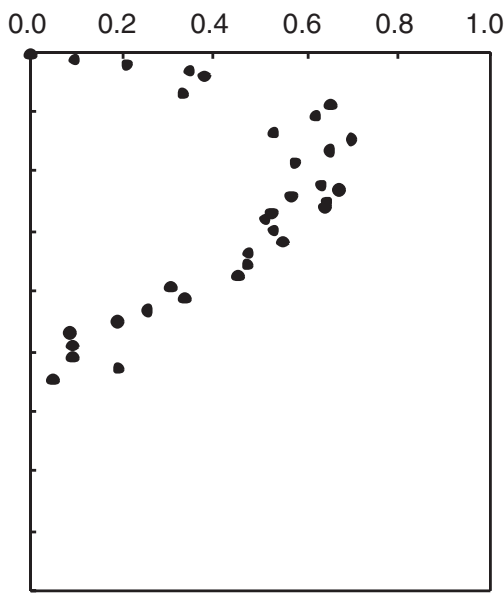

F $\quad \delta^{18} \mathrm{O}-\mathrm{SO}_{4}{ }^{2-}(\%)$

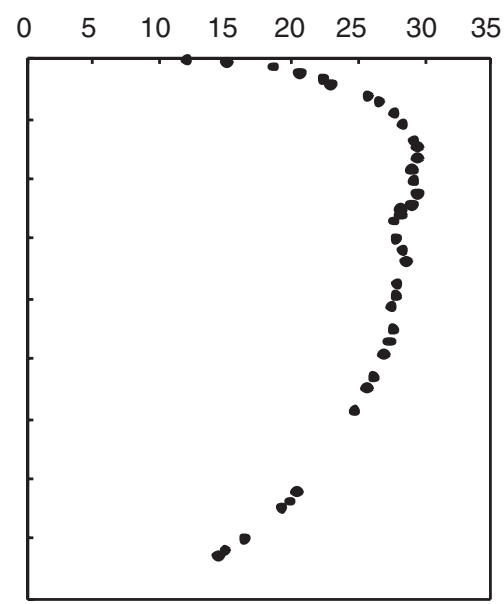


B.B. JøRGENSEN ET AL.

LEg 201 SyNTHESIS: Microbial COMMUNITIES

Figure F4. Cell enumeration data for all Leg 201 sites compared to previously censused sites. Heavy dashed line $=$ geometric means of cell concentrations at previously censused ODP sites. Heavy dotted lines $=2 \sigma$ envelope of cell concentrations at previously censused sites. Light dotted line $=$ geometric means of all Leg 201 cell counts $(y=7.53-0.558 \log [\mathrm{x}]) ; r^{2}=0.25$ (from D'Hondt, Jørgensen, Miller et al., 2003).

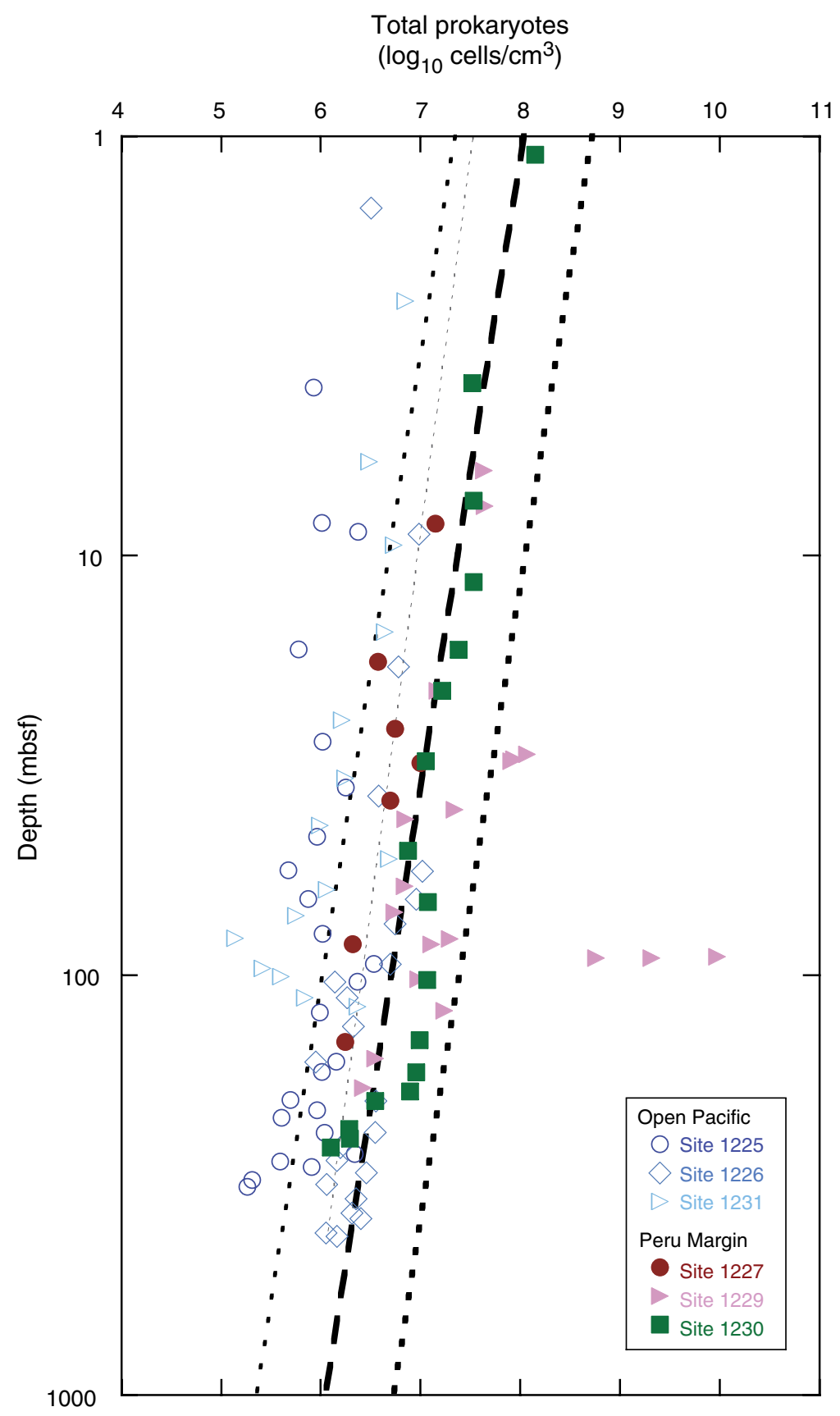


B.B. JøRGENSEN ET AL.

LEg 201 SyNTheSIS: Microbial CoMmunities

Figure F5. Site 1229 on the Peru margin. A. Sulfate and methane distribution in pore water showing two sulfate-methane transitions. B. Distribution of total microbial cell numbers. C. Rates of sulfate reduction (SR). D. Rates of methanogenesis from $\mathrm{H}_{2}$ and $\mathrm{CO}_{2}$ or from acetate (data from D'Hondt, Jørgensen, Miller et al., 2003; Parkes et al., 2005).

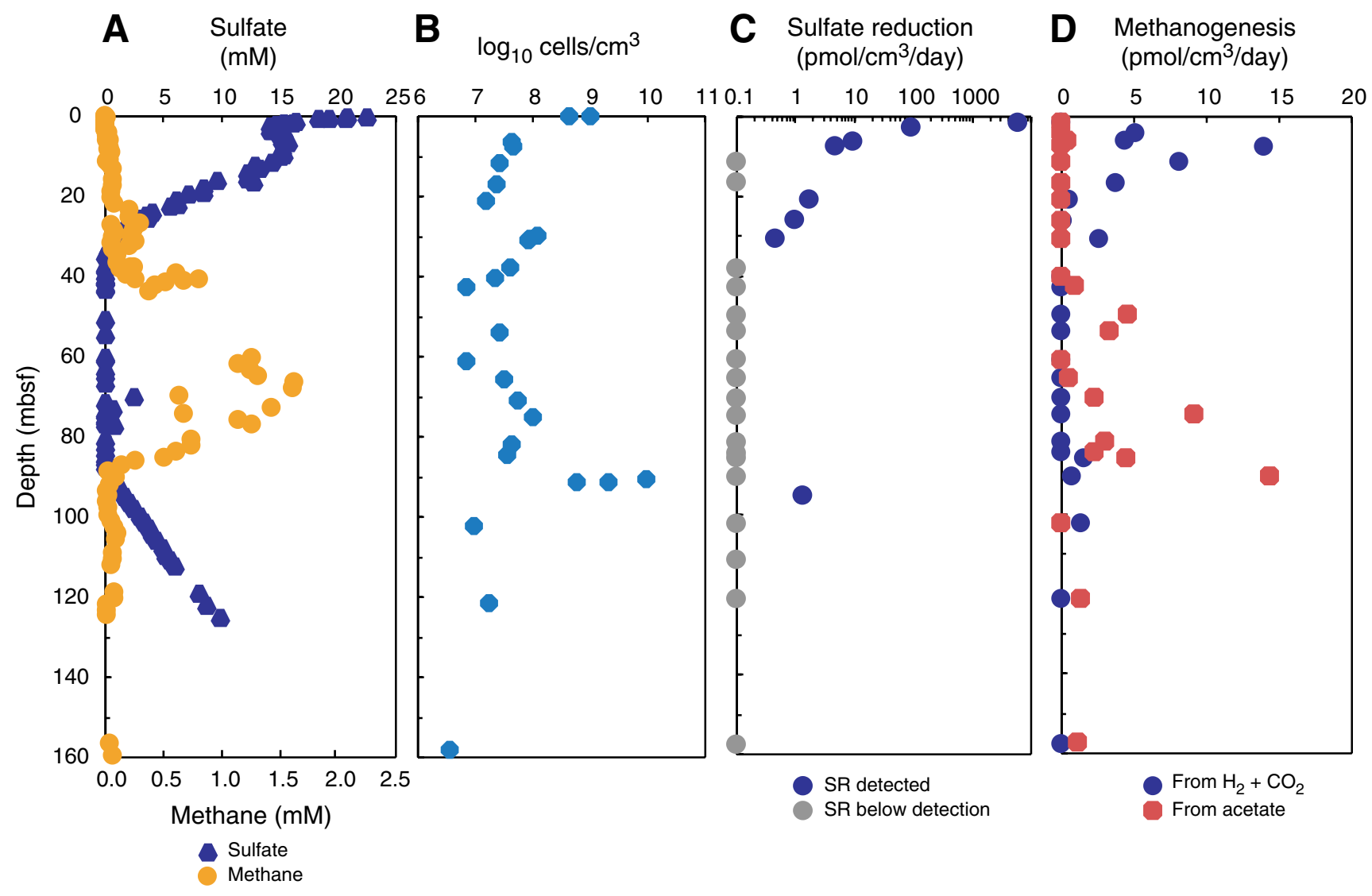


B.B. JøRGENSEN ET AL.

LEg 201 SyNTHESIS: MiCROBIAL CoMmunities

Table T1. Description of sites drilled during Leg 201.

\begin{tabular}{|c|c|c|c|c|c|c|c|c|c|c|}
\hline $\begin{array}{l}\text { Leg } 201 \\
\text { site }\end{array}$ & $\begin{array}{l}\text { Earlier } \\
\text { site }\end{array}$ & Site description & $\begin{array}{l}\text { Water } \\
\text { depth } \\
\text { (m) }\end{array}$ & Latitude & Longitude & $\begin{array}{c}\text { Drilled } \\
\text { holes }(N)\end{array}$ & $\begin{array}{c}\text { TD } \\
\text { (mbsf) }\end{array}$ & $\begin{array}{c}\text { Temperature } \\
\text { range }\left({ }^{\circ} \mathrm{C}\right)\end{array}$ & $\begin{array}{l}\text { TOC } \\
\text { (wt\%) }\end{array}$ & $\begin{array}{c}\text { Sedimentation } \\
\text { rate }(\mathrm{m} / \mathrm{m} . \mathrm{y} .)\end{array}$ \\
\hline \multicolumn{11}{|l|}{$201-$} \\
\hline 1225 & 851 & Open equatorial Pacific, upwelling & 3760 & $02^{\circ} 46,22^{\prime} \mathrm{N}$ & $110^{\circ} 34.31^{\prime} \mathrm{W}$ & 3 & 316 & $1.4-7.0$ & $0-0.9$ & $10-68$ \\
\hline 1226 & 846 & Open equatorial Pacific, upwelling & 3297 & $03^{\circ} 05.70^{\prime} \mathrm{S}$ & $090^{\circ} 49.08^{\prime} \mathrm{W}$ & 5 & 420 & $1.7-24.4$ & $0-2$ & $10-50$ \\
\hline 1227 & 684 & Ocean margin, Peru shelf & 427 & $08^{\circ} 59.49^{\prime} \mathrm{S}$ & $079^{\circ} 54.35^{\prime} \mathrm{W}$ & 5 & 151 & $8.6-16.4$ & $0.6-10.6$ & $8-50$ \\
\hline 1228 & 680 & Ocean margin, Peru shelf & 252 & $11^{\circ} 03.90^{\prime} \mathrm{S}$ & $078^{\circ} 04.67^{\prime} \mathrm{W}$ & 5 & 197 & $12.5-19.3$ & $0.1-13$ & $22-55$ \\
\hline 1229 & 681 & Ocean margin, Peru shelf & 151 & $10^{\circ} 58.60^{\prime} \mathrm{S}$ & $077^{\circ} 57.46^{\prime} \mathrm{W}$ & 5 & 193 & $13.4-20.2$ & $0.8-4$ & 80 \\
\hline 1230 & 685 & Gas hydrate sediment, Peru Trench & 5086 & $09^{\circ} 06.74^{\prime} \mathrm{S}$ & $080^{\circ} 35.01^{\prime} \mathrm{W}$ & 5 & 277 & $1.8-10.3$ & $1.8-4.5$ & 100 \\
\hline 1231 & 321 & Open equatorial Pacific, Peru Basin & 4827 & $12^{\circ} 01.29^{\prime S S}$ & $081^{\circ} 54.24^{\prime} \mathrm{W}$ & 5 & 122 & $1.7-8.6$ & $0-0.6$ & ND \\
\hline
\end{tabular}

Notes: Earlier site numbers indicate sites drilled during previous DSDP or ODP cruises. $N=$ number. TD $=$ total depth drilled. TOC $=$ total organic carbon. ND = not determined. 
B.B. JøRGENSEN ET AL.

LEg 201 SyNTHESIS: Microbial CoMmunities

\section{CHAPTER NOTES*}

N1. Fehn, U., Snyder, G.T., and Muramatsu, Y., submitted. Iodine as a tracer of organic material: ${ }^{129} \mathrm{I}$ results from gas hydrate systems and forearc fluids. $J$. Geochem. Explor.

N2. Snyder, G.T., Fehn, U., and Dickens, G.R., submitted. Are continental margins the largest exogenic iodine reservoir? Implications for marine cycling of organic matter. Earth Planet. Sci. Lett.

N3. Meister, P., McKenzie, J.A., Vasconcelos, C., Bernasconi, S., Frank, M., and Gutjahr, M., submitted. Dolomite formation in the dynamic deep biosphere: results from the Peru margin (ODP Leg 201). Geochim. Cosmochim. Acta. 